
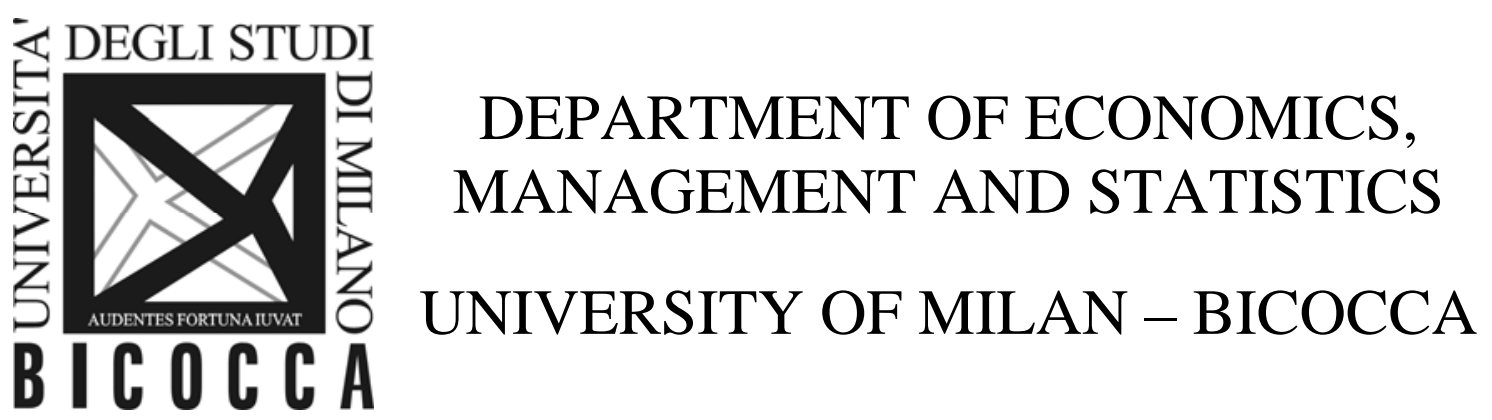

DEMS WORKING PAPER SERIES

\title{
FDI and Heterogeneous Firms: Evidence from BRIC Countries
}

Valeria Gattai, Rajssa Mechelli, Piergiovanna Natale

No. 322 - January 2016

Dipartimento di Economia, Metodi Quantitativi e Strategie di Impresa Università degli Studi di Milano - Bicocca

http://dems.unimib.it/ 


\title{
FDI and Heterogeneous Firms: Evidence from BRIC Countries*
}

\author{
Valeria Gattai \\ (Università degli Studi di Milano-Bicocca) \\ Rajssa Mechelli \\ (Università Cattolica del Sacro Cuore) \\ Piergiovanna Natale \\ (Università degli Studi di Milano-Bicocca)
}

\begin{abstract}
This paper investigates the link between Outward Direct Investment (ODI) and the performance of BRIC firms. Drawing on firm-level data, we introduce a rich taxonomy of ODI that accounts for the decision to invest and the number, destination and ownership structure of foreign affiliates. Through different econometric models and specifications, we consistently demonstrate that BRIC firms engaged in ODI are in the minority, but they outperform domestic enterprises. Moreover, firms selecting less preferred ODI types outperform firms undertaking other ODI strategies.
\end{abstract}

JEL: F23, L25, O57

Keywords: ODI, FDI, Performance, BRIC, Firm-Level Data

\section{Corresponding author}

Piergiovanna Natale

Università degli Studi di Milano-Bicocca

Piazza dell'Ateneo Nuovo 1

20126 Milano

piergiovanna.natale@unimib.it

tel. +390264483095

fax +390264483085

\footnotetext{
* Financial support from Università degli Studi di Milano-Bicocca is gratefully acknowledged. The authors thank participants in seminars at Università degli Studi di Milano-Bicocca and at AIB Mini-Conference 2015 at Bocconi University for helpful comments. All remaining errors are the authors' own.
} 


\section{Introduction}

Outward Direct Investment (ODI) ${ }^{1}$ from developing ${ }^{2}$ countries is a fast-growing phenomenon (Ramamurti, 2008; Ramamurti and Singh, 2008; Sauvant, 2008). In 2014, developing economies accounted for $34.6 \%$ of world ODI flows and $18.7 \%$ of world ODI stocks; moreover, in the same year, half of the twenty largest investor countries worldwide were developing economies (UNCTAD, 2015).

Among these countries, Brazil, Russia, India and China ${ }^{3}$ - the so-called BRIC - feature prominently; over the last decade, outflows from BRIC countries increased by $138 \%$, while outstocks rose by $245 \%$. This evidence fundamentally challenges the old view of these countries as low-cost manufacturing locations; traditionally considered to be destinations for Foreign Direct Investment (FDI), Brazil, Russia, China and India are at present an important source of multinational activity (Schuller and Turner, 2005; Child and Rodrigues, 2005).

In light of the above discussion, this paper empirically investigates the link between ODI and the performance of BRIC firms.

Our research question rests on two strands of literature. On the one hand, starting from the seminal contribution of Bernard and Jensen (1995), many scholars have investigated the relationship between internationalization and performance at the firm level. These researchers suggest that globally engaged enterprises are in the minority, but they outperform domestic firms (for a survey, see Lopez, 2005; Wagner, 2007 and 2012; Greenaway and Kneller, 2007; Singh, 2010; Hayakawa et al., 2012). On the other hand, burgeoning literature on emerging countries' ODI has started to question Dunning's (1993) theory of FDI and to investigate emerging countries' ODI. The most notable finding in this regard is that in the last decade, Multinational Enterprises (MNEs) from emerging economies preferred investing in developed ${ }^{4}$ countries, setting up joint ventures (JVs) and relying on a wide network of foreign affiliates (for a survey, see Amighini et al., 2015; Deng, 2012, 2013; Ramamurti, 2012).

In formulating our research question, we borrow the general interest for the internationalizationperformance nexus from the first strand and the specific focus on emerging countries' ODI from the second. In this way, we are able to reconcile existing studies into a unitary framework and ultimately

\footnotetext{
${ }^{1}$ Consistent with IMF/OECD definitions, we define Foreign Direct Investment (FDI) as an investment in a foreign company in which the investor owns at least 10 percent of the ordinary shares, which is undertaken with the objective of establishing a lasting interest in the country, a long-term relationship, and significant influence on the management of the firm (IMF 1993; and OECD 1996). Since FDI can be both inward and outward, we introduce the label "IDI" (Inward Direct Investment) to denote the former and "ODI" (Outward Direct Investment) to denote the latter. In our terminology, Multinational Enterprises are those engaged in ODI. Note also that we treat the terms "subsidiaries" and "affiliates" as synonymous.

2 In this paper, we consider "emerging", "developing" and "less developed" countries/economies as synonymous.

${ }^{3}$ For the sake of brevity, we refer to the Russian Federation by Russia and to Mainland China by China.

${ }^{4}$ In this paper, we consider "developed" and "advanced" countries/economies as synonyms.
} 
fill gaps in the existing literature. Whereas most contributions on internationalization and performance focus only on the trade-productivity nexus using US or European single-country data, we analyze the case of outward direct investment and study developing economies from a crosscountry perspective. Whereas most contributions on emerging countries' ODI are qualitative or employ country-level data to focus almost exclusively on Chinese and Indian multinationals, we provide a firm-level econometric analysis that embraces Brazil, Russia, India and China in a crosscountry framework.

To the best of our knowledge, this is the first paper dealing with ODI and performance of BRIC enterprises using firm-level information.

Our data are from the Orbis database and cover the whole population of industrial companies headquartered in BRIC countries in 2013, resulting in more than 9,000 observations overall. Drawing on these data, we introduce quite a rich taxonomy of ODI that accounts for the decision to invest and the number, destination and ownership structure of foreign affiliates.

This approach allows us to uncover a number of stylized facts that complement previous findings on related issues. First, BRIC firms engaged in ODI are in the minority. Second, within the group of BRIC investors, those firms having more than five foreign subsidiaries, investing in developing countries, or operating in joint ventures are in the minority. Third, BRIC firms engaged in ODI outperform domestic enterprises. Fourth, within the group of BRIC investors, those firms having more than five foreign subsidiaries, investing in developing countries, or operating in joint ventures outperform those firms that select other ODI strategies.

These results are robust to several econometric models, definitions of ODI, measures of performance and specifications including firm, industry and country controls. Moreover, they point in the direction of a strong correlation between ODI and performance. Not only do those firms that are engaged in ODI outperform domestic enterprises, but also those firms that select less preferred ODI types are the best performing, which is something that previous studies could not assert. Indeed, taking either the internationalization and performance approach or the emerging countries' ODI approach, they could not explore the potential benefits of marrying the empirical framework of the former with the ODI taxonomy developed by the latter. On the contrary, we show that the positive correlation between ODI and performance is both a matter of involvement versus non-involvement in ODI and a matter of the type of ODI that a firm undertakes.

The remainder of the paper is organized as follows. Section 2 provides an overview of ODI from BRIC countries. Section 3 reviews the two strands of literature that inspire the present research. In Section 4, we present our data, introduce our taxonomy of ODI, and discuss summary statistics. In 
Section 5, we describe econometric specifications and results. Section 6 provides our conclusion and suggests future lines of research.

\section{ODI from BRIC Countries: An Overview}

The last twenty years have witnessed a steady increase in FDI directed to and originating from developing economies. In 1995, developing economies were on the receiving end of $34.5 \%$ of world Inward Direct Investment (IDI) flows. In 2014, they were the destination of 55\% of world IDI flows and accounted for a third of world IDI stocks. Among developing economies, BRIC countries feature prominently as a destination of IDI: in 2014, BRIC received $20 \%$ of world IDI flows and accounted for $9.5 \%$ of world IDI stocks.

Regardless of how striking these data may appear, developing economies exhibit even more impressive figures concerning ODI. In 1995, developing economies contributed $14.6 \%$ to world ODI flows and $7.8 \%$ to world ODI stocks; in 2014, they contributed $34.6 \%$ and $18.7 \%$, respectively. Among developing economies, the BRIC countries are important origins of ODI. In 2014, the BRIC countries' share in world ODI flows was $13.2 \%$, while the BRIC countries' share in world ODI stocks was $6.2 \%$. Notably, ODI from BRIC countries has increased much faster than IDI to BRIC countries over the last two decades (Table 1).

[Table 1]

These remarkable changes are explained by the outstanding GDP annual growth rates experienced by BRIC countries since 1995 and their unexpected resilience throughout the financial crisis. During the 2008 to 2014 period, GDP in BRIC countries grew at an average yearly rate that exceeded 5\%. Even the most recent slowdown of these countries' economies ${ }^{5}$ had little impact on ODI.

A number of country-specific factors also fostered ODI from BRIC countries.

Brazilian firms have invested abroad since the late 1970s; however, it is only since the early 2000s that improved conditions in the domestic capital market ${ }^{6}$ have allowed firms in exporting sectors to raise capital on a large scale and to expand their market share abroad via ODI (Arbix and Caseiro, 2011). As in the past, Brazilian ODI is presently driven by conditions on the domestic capital market. Credit conditions have tightened in the wake of the 2007 financial crisis, which helps to explain why ODI flows have been negative since 2009. Brazil has not yet developed a policy framework in support of ODI. To date, the only interventions have been loans selectively offered to "national champions" by BNDES-the country major development bank-at an interest rate below market value. ${ }^{7}$

\footnotetext{
${ }^{5}$ The average yearly growth rate over the years 2011-2014 fell to around $4.5 \%$.

${ }^{6}$ In the early 2000s, Brazil's foreign reserves greatly increased, due to large IDI flows and the rise in the price of commodities.

${ }^{7}$ For more detailed information, see De Abreu Campanario et al. (2013).
} 
Russia is among the largest investor countries worldwide. Over the last two decades, ODI has increased considerably faster than IDI. In the early 2000s, Russian conglomerates pursued natural and strategic resource-seeking ODI (UNCTAD, 2005). One decade later, there has been a shift toward investment in knowledge-based sectors and services. A distinctive feature of Russian internationalization is the prevalence of large private companies. ${ }^{8}$ Support to ODI by Russian authorities is generally restricted to soft measures and tax exemptions, while intervention to alleviate financing constraints has not yet been contemplated (Sauvant et al., 2014). The tightening of credit conditions on international markets and the economic sanctions imposed in 2014 by the European Union and the US in response to Russian operations in Crimea explain the recent fall in ODI flows and, to a lesser extent, stocks from Russia (UNCTAD, 2015).

While small compared with ODI from other BRIC countries, Indian ODI has grown at rates unknown in Brazil, Russia or China during the last two decades. The primary factor behind Indian ODI is a regulatory environment conducive to private firms' participation in global markets (Export-Import Bank of India, 2014). Indian authorities provide debt and equity financing to firms operating abroad, irrespective of their size. Insurance against political risk is also guaranteed by a government agency. Finally, the Export-Import Bank of India and other government agencies offer "soft" services - such as reports on investment opportunities, consultancy and staff training services - though tax exemptions are not yet available to ODI firms. ${ }^{9}$ Because it is primarily directed toward developed countries (Garcia-Herrero and Deorukhakar, 2014), Indian market-seeking ODI flows declined over the period of 2009 to 2013 but began to rise once more in 2014.

The largest FDI recipient in 2014, China is also the third largest investor country worldwide (UNCTAD, 2015). Over the last decade, Chinese outflows increased six-fold and outstocks nearly ten-fold, outpacing inflows and instocks during the same period. The distinctive feature of Chinese ODI is its careful management by local authorities who have implemented a well-defined regulatory framework since the launch of the so-called "Go out" policy in 2000 (Sauvant et al., 2014; GarciaHerreri et al., 2015). The adoption of the 12th Five Year Plan in 2010 imparted further acceleration and favored a change of target for Chinese ODI. Resources are being shifted away from natural resource-seeking projects and invested instead into advanced technology and high-quality brands (The Economist, 2013, 2015). Currently, China supports ODI through a variety of home-country measures. These measures include: i) "soft" measures, such as the collection and transmission of information, local support and special funding for the training of expatriates; ii) financial support in the form of loans and equity participation; iii) tax incentives; iv) investment insurance.

\footnotetext{
${ }^{8}$ Some commentators argue that the size of many Russian operations abroad belies their nature as "safety nests," designed to shelter capital from domestic turmoil (Liuhto and Majuri,2014).

${ }^{9}$ For more detailed information, see Sauvant et al. (2014).
} 


\section{Literature Review}

In this section, we review the two strands of literature that inspire the present research.

\subsection{Internationalization and performance}

The seminal contribution of Bernard and Jensen (1995) started a literature on internationalization and performance at the firm level. No matter the year and the country of the analysis, empirical evidence suggests that globally engaged enterprises are "the happy few" (Mayer and Ottaviano, 2007), i.e., they are in the minority, but they outperform domestic firms on a number of variables. ${ }^{10}$

Two alternatives, although not mutually exclusive hypotheses, explain the positive correlation between internationalization and performance.

According to the self-selection (SS) hypothesis, there are ex ante performance differences between firms that become international and firms that keep serving the domestic market. This is because operating abroad involves additional costs that constitute an entry barrier to less successful firms (Melitz, 2003). ${ }^{11}$ According to the learning-by-internationalization (LI) hypothesis, ex post performance differences depend instead on firms' exposure to the international arena (Clerides et al., 1998). Indeed, by interacting with foreign competitors and customers, firms are likely to increase their scale, become more efficient and innovate to keep pace with their rivals.

While the early contributions on internationalization and performance mostly focused on developed countries, large firm-level datasets have recently become available for developing countries, as well, which has triggered new empirical research on the topic. ${ }^{12}$

Given our interest in BRIC countries, we conduct a more specific review of the papers that address the internationalization and performance of firms headquartered in Brazil, Russia, India and China. ${ }^{13}$ To the best of our knowledge, 11 papers address the internationalization and performance of Chinese enterprises (Dai and Yu, 2013; Du et al., 2012; Kraay, 1999; Li and Yin, 2010; Lu, 2012 Ma et al., 2014; Park et al., 2010; Van Biesebroeck, 2014; Wang et al., 2009; Yang, 2008; Yang and Mallick, 2010); three focus on India (Haidar, 2012; Mallick and Yang, 2013; Demirbas et al., 2013), and none deal with either Brazil or Russia.

\footnotetext{
${ }^{10}$ For a survey, see Lopez (2005), Wagner (2007, 2012), Greenaway and Kneller (2007), Singh (2010), and Hayakawa et al. (2012).

${ }^{11}$ The core Melitz model has recently been developed in various ways, giving rise to a well-established body of theories on heterogeneous firms and trade. For a survey, see Redding (2011).

${ }^{12}$ See, for instance, Alvarez and Lopez (2005) for Chile, Van Biesebroeck (2005) for sub-Saharan Africa, Fafchamps et al. (2008) for Morocco, Yasar and Rejesus (2005) for Turkey, Djankov and Hoeckman (2000) for Czech Republic, Fernandes (2007) for Colombia, Blalock and Gertler (2004) for Indonesia, Park et al. (2010) for China, and Haidar (2012) for India.

${ }^{13}$ Consistent with the framework delineated above, we focus on papers addressing the internationalization-performance nexus from an International Economics perspective. This is to say that all contributions reviewed below draw theoretical insights from Melitz (2003) and Clerides et al. (1998) and set their empirical analysis in a microeconomic framework à la Bernard and Jensen (1995). For a survey on internationalization and performance from an International Business perspective, see Li (2007).
} 
Concerning internationalization measures, the existing literature has focused almost exclusively on exports, with the only exception being Demirbas et al. (2013), who analyze trade and ODI. As for performance, previous studies can be grouped into two broad classes. On the one hand, Dai and $\mathrm{Yu}$ (2011), Du et al. (2012), Kraay (1999), Li and Yin (2010), Van Biesebroeck (2014) and Wang et al. (2009) focus only on productivity, to capture the original spirit of Melitz (2003) and Clerides et al. (1998). On the other hand, Demirbas et al. (2013), Haidar (2012), Lu (2012), Ma et al. (2014), Mallick and Yang (2013), Park et al. (2010), Yang (2008) and Yang and Mallick (2010) relax the notion of firm heterogeneity and consider a wider array of performance variables - such as value added, sales, employment, capital intensity, R\&D intensity, ROA and ROE - that add to productivity. Once internationalization and performance are defined, the model specification follows either the SS or LI hypothesis. In the former case, internationalization is regressed on firm-level performance (Demirbas et al., 2013; Lu, 2012 Haidar, 2012; Li and Yin, 2010; Ma et al., 2014; Mallick and Yang, 2013; Wang et al., 2009; Yang and Mallick, 2010). In the latter case, firm-level performance is regressed on internationalization variables (Dai and Yu, 2011; Du et al., 2012; Kraay, 1999; Park et al., 2010; Yang, 2008; Haidar, 2012; Li and Yin, 2010; Ma et al., 2014; Mallick and Yang, 2013; Wang et al., 2009; Yang and Mallick, 2010). Empirical results generally point to a statistically significant and positive correlation between internationalization and performance. As predicted by the theory, international firms are in the minority, but they exhibit superior performance compared with purely domestic enterprises. ${ }^{14}$

While these results are firmly established within the sub-literature on internationalization and performance in BRIC countries, we believe two gaps still plague existing studies, thereby limiting their scope. First, most contributions tend to adopt a rather narrow definition of internationalization that fully coincides with exports. Although this choice might depend on data availability, it becomes a serious limitation if one considers the impressive surge in ODI from emerging countries. Second, we are not aware of any single study covering all BRIC countries in a unified empirical framework. While it is surely interesting to focus on China or India - countries that feature prominently among developing economies - we believe that much more can be said about internationalization and performance accounting for country- plus firm-level heterogeneity.

To address these issues and potentially contribute to the ongoing debate, we focus on ODI rather than exports. Drawing complementary insights from the literature on emerging countries' ODI, ${ }^{15}$ we dissect outward direct investment by number, destination and ownership structure of foreign

\footnotetext{
14 The only papers pointing to a negative or insignificant correlation between exports and productivity are Yang (2008) and Li and Yin (2010). They both focus on Chinese enterprises and account for such a paradox with explanations based on factor intensity (Yang, 2008), processing trade (Li and Yin, 2010) and data limitations (Li and Yin, 2010).

${ }^{15}$ See Section 3.2.
} 
affiliates. Moreover, we provide a cross-country empirical study to check the robustness of previous results to the inclusion of highly heterogeneous home markets.

\subsection{Emerging countries' ODI}

The recent surge of emerging countries' ODI has stimulated a lively debate regarding their determinants and characteristics. ${ }^{16}$

As far as determinants are concerned, the question is whether emerging countries' ODI can be rationalized through the same conceptual framework as advanced economies' ODI. According to Dunning (1993), advanced economies' ODI are a means to capitalize abroad certain OwnershipLocation-Internalization (OLI) advantages that are owned before internationalization. Some authors claim that the OLI theory has only limited power in interpreting developing countries' ODI because MNEs from emerging economies lack the same advantages that the theory emphasizes as a prerequisite for investing abroad. Thus, they engage in asset-seeking, rather than asset-exploiting, ODI, expanding overseas to access those resources that they are not able to secure domestically (Mathews, 2006; Deng, 2007; Luo and Tung, 2007; Athreye and Kapur, 2009; Child and Rodrigues, 2005; Zhang, 2005; Sutherland and Ning, 2011). Other authors suggest instead that the traditional theory can be adapted to account for all possible types of ODI. Indeed, MNEs from developing countries do possess some OLI advantages, even though they are different from those of MNEs from developed countries. While the latter traditionally rely on human capital, reputation and technology, the former count on process capabilities, management and corporate entrepreneurship, parental networks, flexibility, and social and networking skills (Fortanier and Tulder, 2009; Yiu et al., 2007; Buckley et al., 2007; UNCATD, 2006; Narula, 2006). Despite their different positions on Dunning's theory, authors generally agree on some typical push and pull factors driving developing countries' ODI. Pull factors include market- and resource-seeking motivations (De Beule et al., 2014; Fortanier and Tulder, 2009; Niosi and Tschang, 2009; Yeung and Liu, 2008; Deng, 2004 and 2007; Schuller and Turner, 2005; Zhang, 2005; Sutherland and Ning, 2011; Cui et al., 2014). Push factors range from government support to the availability of capital to invest and over-capacity in the domestic market (Kumar and Chadha, 2009; Athreye and Godley, 2009; Duysters et al., 2009; Yeung and Liu, 2008; Deng, 2004 and 2007; Schuller and Turner, 2005; Wang et al., 2012; Cui and Jiang, 2012).

As far as characteristics are concerned, the existing studies reveal that emerging countries' ODI follow some typical patterns in terms of number, destination and ownership structure of foreign affiliates. During the 1990s, emerging countries' ODI was usually directed toward emerging economies, managed via wholly foreign-owned enterprises (WFOEs), and involved a limited number of foreign affiliates. One decade later, this picture started to change, with certain MNEs preferring

\footnotetext{
${ }^{16}$ For a survey, see Ramamurti (2012), Deng (2012, 2013) and Amighini et al. (2015).
} 
JV rather WFOE, targeting developed in addition to developing hosts, and relying on a wider network of foreign affiliates (Child and Rodrigues, 2005; Schuller and Turner, 2005; Liu and Buck, 2009; Yiu et al., 2007; Aybar and Ficici, 2009; Gubbi et al., 2010; Makino et al., 2002). As noted in Sutherland and Ning (2011) and Piscitello et al. (2015), to understand these trends, one needs to consider how determinants and characteristics of emerging countries' ODI co-evolve over time. During the 1990s, multinationals from developing economies were large state-owned enterprises, enjoying massive government support and expanding abroad for (natural) resource-seeking motivations. For these reasons, they mostly targeted developing countries, and they were used to operating alone within the boundaries of wholly foreign-owned enterprises. A few years later, many private enterprises entered into the world stage, responding to market competition. This is precisely the type of MNE that expands overseas due to over-capacity in the domestic market or availability of capital to invest and engage in (strategic) resource-seeking ODI. Not surprisingly, these firms prefer entering into developed rather than developing countries and setting many joint ventures instead of a few WFOEs. Proceeding in this way, they are able to exploit all potential links with local enterprises and access key resources.

Despite the large number of contributions on emerging countries' ODI, we believe that two important issues have remained unexplored. First, most studies are either descriptive or based on country-level data. ${ }^{17}$ While they provide a general portrait of emerging countries' ODI, they do not enter into the specific details of firm-level analysis. Moreover, the existing contributions focus almost exclusively on China and India with little attention paid to ODI from other developing economies. ${ }^{18}$ Even though China and India feature prominently within the group of emerging economies, we believe new insights could be drawn that embrace a wider spectrum of countries, which would also increase the scope for generalizability of the empirical results.

To address these issues and potentially contribute to the ongoing debate, we provide a quantitative analysis based on firm-level data. Drawing complementary insights from the literature on internationalization and performance, we do not simply portray BRIC ODI, but we rather investigate how this portrait associates with heterogeneous performance. Moreover, as mentioned above, we develop a cross-country empirical study to check the robustness of previous results to the inclusion of highly heterogeneous home markets.

\footnotetext{
${ }^{17}$ A few exceptions that provide micro-level empirical analysis are Wang et al. (2012), Cozza et al. (2015), Edamura et al. (2014), and Chen and Tang (2014).

18 A few exceptions are Cuervo-Cazurra (2007) and Ramsey et al. (2012) on Latin America and Andreff (2003) on transition economies.
} 


\section{Data and Descriptive Statistics}

\subsection{Data}

For the purpose of the present research, we employ firm-level information from Orbis, a commercial dataset issued by Bureau van Dijk. Orbis contains administrative data on 130 million firms from more than 100 countries and exhibits a number of distinctive features. ${ }^{19}$ Unlike other administrative firmlevel databases, Orbis covers firms small and large and listed and unlisted from all sectors and all continents; unlike census data, Orbis reports indicators, real and financial variables and a large set of information about firms' affiliates, including their number, destination and ownership structure.

For all of these reasons, we believe that Orbis is an appropriate database with which we can investigate the link between ODI and the performance of firms headquartered in BRIC countries.

Our measures of performance are selected from within the wide array of indicators, real and financial variables present at the firm level. In contrast, our measures of ODI draw on Orbis information regarding subsidiaries. At this stage, it should be mentioned that in Orbis, performance data cover a 10-year period, while data on subsidiaries are available only for the previous year. This imposes constraints on empirical analysis that prevent, for instance, the use of panel techniques. For the purpose of the present research, data have been downloaded in 2014: Our performance variables cover the period of 2009 to $2013,{ }^{20}$ while subsidiaries data are a snapshot of $2013 .^{21}$

Our database covers the whole set of industrial companies included in Orbis and headquartered in Brazil, Russia, India and China in 2013, amounting to 9,527 firms overall. This sample is the result of a trimming procedure that drops firms with negative values for sales, number of employees, tangible and intangible assets and firms with missing information about subsidiaries. ${ }^{22}$

From a firm-level point of view, our sample is skewed toward very large (96\%), listed (92\%) and old $(70 \%)$ companies $^{23}$ that account for the vast majority of firms headquartered in BRIC countries.

At the industry level, $60 \%$ of the firms belong to the manufacturing sector, followed by the wholesale and retail trade (10\%) and Information \& Communication Technologies (7\%); other NACE 2-digit sectors, although represented, are quite marginal.

Lastly, from a country-level perspective, most firms are from India (45\%) and China (37\%), while Russia and Brazil account for a comparatively small $12 \%$ and $6 \%$, respectively.

Drawing on these data, we unveil a number of stylized facts regarding ODI and performance in BRIC countries. To this end, we proceed in two steps. First, we characterize our sampled firms' involvement

\footnotetext{
${ }^{19}$ For a discussion about the reliability of Orbis data, see Kalemli-Ozcan et al. (2015).

${ }^{20}$ Missing values are a serious concern for earlier periods.

${ }^{21}$ Note that sanctions related to the Crimean crisis were imposed on Russia in March 2014 and are thus of no concern for our work

${ }^{22}$ Our initial population counted 9,570 firms.

$2370 \%$ of the sampled firms are at least 20 years old and the average age is 26 .
} 
in outward direct investment, introducing a notably rich taxonomy of ODI (4.2). Second, we study performance differentials among firms exhibiting different ODI involvement. This last issue is explored by both descriptive statistics (4.3) and econometric analysis (5).

\subsection{Taxonomy of ODI}

Our taxonomy of ODI exploits Orbis data on foreign affiliates. For every firm, Orbis provides the complete list of subsidiaries; then, for every subsidiary, it shows the host-country isocode and the percentage of ownership. Because Orbis displays no information regarding either the flows or the stocks of outgoing capital, we can infer ODI involvement only by looking at the host-country isocode. Based on the available information, we distinguish between $O D I$ and noODI firms; namely, those having at least one foreign subsidiary and those having none. ${ }^{24}$

As shown in Table 2, ODI firms are in the minority. If one considers the overall sample, $13 \%$ of firms are engaged in ODI. Evidence is fully consistent when focusing on single countries, with maximum ODI involvement in Brazil (18\%) and minimum ODI involvement in Russia (11\%). This delivers our first stylized fact that can be summarized as follows:

Fact 1. BRIC firms engaged in ODI are in the minority.

Fact 1 seems to suggest that ODI from BRIC countries is confined to a handful of multinationals that are responsible for the impressive shares of outflows and outstocks reported in Section 2.

After distinguishing between $O D I$ and noODI firms, we further dissect the former by looking at the number, destination and ownership structure of foreign affiliates. This approach results in a notably rich taxonomy of outward direct investment that groups BRIC firms into mutually exclusive classes of ODI involvement.

As far as the number of foreign subsidiaries is concerned, we distinguish between ODI_1,ODI_2-5 and $O D I_{-}>5$ firms; namely, those having one, from two to five or more than five foreign affiliates. Our evidence reveals that most of the sample falls under the $O D I \_l$ class with very few firms having more than five foreign subsidiaries. This findings hold for BRIC in general - where ODI_1,ODI_25 and $O D I_{-}>5$ firms account for $49 \%, 36 \%$ and 15\%, respectively - and for every single country (Table 2).

As far as the destination is concerned, we distinguish between ODI_LDC, ODI_DC and $O D I \_D C \& L D C$ firms; namely, those with foreign subsidiaries only in Less Developed Countries (LDCs), only in Developed Countries (DCs) and in both LDCs and DCs. ${ }^{25}$ Consistent with the portrait of emerging countries' ODI traced in Section 3, developed countries are the favorite destination for BRIC outward direct investment. Indeed, $56 \%$ of the overall sample has ODI only in DCs, $29 \%$ in

\footnotetext{
${ }^{24}$ See Table A1, in the Appendix, for a full description of variables.

${ }^{25}$ For a list of less developed and developed countries, see IMF (2014).
} 
both DCs and LDCs and 15\% exclusively in LDCs. Our evidence, reported in Table 2, is broadly consistent when considering the single countries, rather than the aggregated BRIC data.

As far as the ownership structure is concerned, we distinguish between $O D I_{-} J V, O D I_{-} W F O E$ and $O D I J V \& W F O E$ firms; namely, those with only JV-types of foreign affiliates, those with only WFOE-types of foreign affiliates, and those holding both JVs and WFOEs. ${ }^{26}$ Our evidence suggests that WFOE is the favorite entry mode of BRIC multinationals. Indeed, $45 \%$ of the overall sample falls in the ODI_WFOE class followed by $32 \%$ belonging to the ODI_JV\&WFOE class and $23 \%$ engaging in JV alone. Evidence in fully consistent when switching from a cross- to a single-country perspective (Table 2).

This delivers our second stylized fact that can be summarized as follows:

Fact 2. Within the group of BRIC investors, firms having more than five foreign subsidiaries, investing in less developed countries, or operating in joint ventures are in the minority.

[Table 2]

\subsection{Performance by ODI involvement}

After introducing our taxonomy of ODI, we study performance differentials among firms exhibiting heterogeneous ODI involvement.

Table $3^{27}$ provides descriptive statistics regarding a wide array of performance variables, including Sales, Profit, number of Employees, Value added, labor productivity (Lab Prod), total factor productivity (TFP), intangible assets (Int assets), tangible assets (Tan assets) and enterprise value (Ent value). In selecting these variables, we try to capture different aspects of firms' performance that are related to their economic, innovation and financial strength. Sales, Profit, Employees, Value added, Lab Prod, and TFP can be regarded as purely economic variables, as a proxy for firms' scale and efficiency. Intangible assets (Int assets) are mostly related to firms' innovative activities, while Ent value pertains to financial stability. The reader is referred to Table A1, in the Appendix, for a full description of these variables.

The second column of Table 3 reports the mean of every performance variable for noODI firms that are our base group. Subsequent columns then display the difference in means between firms engaged in ODI and noODI firms. Mean comparison tests are also run to check whether these differences are statistically significant.

Based on the available information, we first compare noODI versus $O D I$ firms. As shown in Table 3 , $O D I$ firms exhibit superior performance compared with noODI firms for every performance variable.

\footnotetext{
${ }^{26}$ In this paper, we classify as WFOEs all subsidiaries having more than $95 \%$ foreign participation.

${ }^{27}$ For the sake of readability, Tables 3-7 provide empirical evidence on the overall sample of BRIC firms. Single-country results are available from the authors upon request.
} 
Indeed, all differences in the means are positive and statistically significant, which leads to our third stylized fact that can be summarized as follows:

Fact 3. BRIC firms engaged in ODI outperform domestic enterprises.

To exploit the richness of our ODI taxonomy, we next compare noODI versus ODI firms by number, destination and ownership structure of foreign affiliates. This approach enables a deeper understanding of the correlation between ODI and performance.

If we consider ODI by number of foreign subsidiaries, all differences in the means are positive and statistically significant. Moreover, $O D I>5$ firms differ from noODI firms more than $O D I$ 2-5 firms do; $O D I \_2-5$ firms, in turn, differ from noODI firms more than $O D I \_1$ firms do. This means that the larger the number of foreign subsidiaries - pointing to a deeper ODI involvement - the wider the difference in performance from the base group.

Next, we focus on ODI by destination. As shown in Table 3, all differences in the means are positive and statistically significant. Moreover, the largest differences accrue to ODI_LDC\&DC firms, suggesting that the larger the spectrum of destinations - pointing to a deeper ODI experience - the wider the gap with the base group. Interestingly, $O D I \_L D C$ firms perform better than $O D I \_D C$ firms in terms of Profit, Value added, Lab prod, Int assets, Tan assets, Ent value and TFP; however, BRIC firms investing only in developed countries present higher Sales and Employees compared with those investing only in less developed countries.

Lastly, we consider ODI by ownership structure of foreign affiliates. All differences, shown in Table 3, are positive and statistically significant. Moreover, a neat ranking emerges among the mutually exclusive classes designated $O D I \_J V, O D I \_W F O E$ and $O D I \_J V \& W F O E$. Not surprisingly, $O D I J J \& W W O E$ firms are those that differ the most from noODI firms. This is consistent with our previous result that the deeper the ODI experience, the wider the performance gap with the base group. Notably, $O D I J J V$ firms perform better than $O D I \_W F O E$ firms with respect to all variables displayed in Table 3. Put another way, shared ownership of foreign affiliates seems to couple with outstanding performance more than does full ownership.

Fact 4 summarizes the above-mentioned results.

Fact 4. Within the group of BRIC investors, those firms having more than five foreign subsidiaries, investing in developing countries, or operating in joint ventures outperform those firms that select other ODI strategies.

[Table 3] 


\section{Econometric Analysis}

This section further analyzes the link between ODI and the performance of BRIC firms through econometric regressions. For expositional convenience, we use the same notation as in Section 4. In particular, we stick to the same variable names to facilitate comparisons with our previous results. Taking advantage of our rich taxonomy of ODI, we estimate four econometric models, in the spirit of the self-selection hypothesis. ${ }^{28}$

The first model compares $O D I$ versus noODI firms, according to Equation (1):

$$
\text { ODI }_{i}=\alpha \text { performance }_{i}+\beta \text { firm controls }_{i}+\gamma \text { industry controls } \text { cin }_{i}+\sigma \text { country controls }_{i}+\varepsilon_{i}
$$

The dependent variable $O D I$ is a dummy equal to 1 for firms having at least one foreign subsidiary. Accordingly, Equation (1) is estimated through the Logit model.

Covariates consist of three main groups: performance is a measure of firm $i$ 's performance, according to the economic, innovation and financial variables already delineated in Table 3 . They range from Sales to Profit, from Employees to Value added, from Lab prod to TFP and from Ent value to Int assets and Tan assets. Adding to performance, firm controls is a matrix containing firm-level variables that may affect the ODI decision but over which we do not have any specific prior; they include firm's age, a dummy for large companies and a dummy for listed companies. ${ }^{29}$ Lastly, industry controls and country controls contain industry and country fixed effects. For what concerns the industry, 21 dummies are included to study the potential effects of belonging to any NACE 2-digit sector on the ODI decision. For what concerns the country, four dummies control for firms being headquartered in Brazil, Russia, India and China. The Appendix provides a complete variables description (Table A1), some summary statistics (Table A2) and the correlation matrix (Table A3) of performance regressors.

At this stage, it is worth mentioning that our dependent variable refers to 2013 while covariates are as of 2012. We are aware that the cross-sectional nature of our data does not allow for any proper causality analysis. For this reason, estimation results should be interpreted as a convenient way of summarizing statistical regularities more than showing the exact direction of causality. However, we introduce 1-year lag to avoid complete simultaneity. ${ }^{30}$

\footnotetext{
${ }^{28}$ See Section 3.1 on this point. Our econometric specification follows SS due to data constraints. As mentioned in Section 4, our ODI data refer to 2013, while performance data cover the 2009-2013 period. Hence, regressing ODI on performance permits us to include lagged independent variables.

${ }^{29}$ Unfortunately, Orbis provides no information on export or import status; therefore, we cannot control for them.

30 We tried alternative specifications in which the 2013 ODI was regressed on 2-, 3- or 4-year lagged independent variables. However, this came at the expense of a lower number of observations, due to missing values. Since results do not qualitatively change, considering firms' performance in any year between 2009 and 2012, we stick to 2012 to minimize missing values. More results are available from the authors upon request
} 
Table 4 displays our Logit estimates of Equation (1). For every performance variable, two specifications are shown: in (i) $O D I$ is regressed only on performance variables, while in (ii) firm, industry and country controls are included as a robustness check. Note too that we display both pure and mixed specifications. In the former, we regress $O D I$ on every single performance variable to highlight the basic correlations; in the latter, we regress $O D I$ on a group of performance variables that are selected according to their correlation matrix (Table A3).

[Table 4]

Our most notable finding is that firms exhibiting superior performance are more likely to engage in ODI: Sales, Profit, Employees, Value added, Lab prod, TFP, Int assets, Tan assets and Ent value all turn out to be statistically significant with a positive sign, meaning that better enterprises are more prone to outward direct investment. This result is robust to firm, industry and country controls, and it holds irrespective of the specifications and performance measures, supporting what we have previously denoted as Fact 3 .

Interestingly, the positive correlation between ODI and performance that we document for BRIC enterprises is fully consistent with previous results on MNEs from advanced economies (Murakami, 2005; Kimura and Kiyota, 2006; Hijezen et al., 2010, 2011; Barba Navaretti and Castellani, 2008; Castellani, 2002; Castellani et al., 2008; Barba Navaretti et al., 2010). Moreover, as for the evidence from advanced economies, it can be framed according to both the self-selection and the learning-byinternationalization hypothesis. On the one hand, enterprises that are better ex ante are more likely to self-select into foreign markets because they can afford the extra costs of operating abroad. On the other hand, ODI might translate into enhanced ex post performance due to internationalization-driven learning.

To further explore the link between ODI and performance, our second model focuses on ODI according to the number of foreign affiliates. Equation (2) is set accordingly:

$$
\text { N.subsidiaries }_{i}=\alpha \text { performance }_{i}+\beta \text { firm controls }_{i}+\gamma \text { industry controls } \text { crountry }_{i}+\sigma \text { controls }_{i}+\varepsilon_{i}
$$

The dependent variable $N$. subsidiaries captures the number of foreign affiliates. This is an example of count data that takes the form of non-negative integer values. Accordingly, Equation (2) is estimated through the Poisson model. Covariates and econometric specifications are the same as before to permit comparisons with our previous results.

Notably, all incidence rate ratios displayed in Table 5 are larger than one, pointing to a positive and statistically significant correlation between firms' performance and ODI. The larger the firms' Sales, Profit, Employees, Value added, Lab prod, TFP, Int assets, Tan assets and Ent value, the higher the 
number of foreign subsidiaries. This finding is robust to firm, industry and country controls, and it holds irrespective of the specifications and performance measures.

Interestingly, our evidence is consistent with both the SS and the LI theoretical frameworks. In the spirit of Melitz (2003), the best firms are more likely to build a wider network of foreign affiliates, which implies that they can afford the extra costs of ODI. Along the lines of the argument advanced by Clerides et al. (1998), having more subsidiaries abroad maximizes learning chances through interaction with local competitors and customers.

\section{[Table 5]}

Our third model estimates ODI by destination. Equation (3) is set as follows:

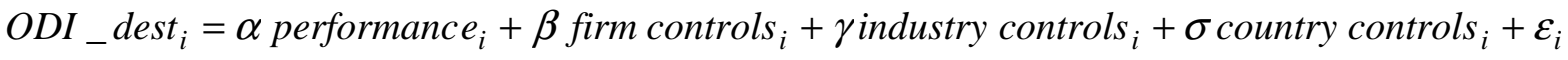

The only difference, compared with Equations (1) and (2), lays in our choice of the dependent variable. $O D I$ dest is a discrete variable that is equal to 0 if the firm has no foreign subsidiaries; 1 if the firm has foreign subsidiaries only in developed countries; 2 if the firm has foreign subsidiaries only in less developed countries; and 3 if the firm has foreign subsidiaries in both developed and less developed countries. ODI_dest clearly combines the mutually exclusive cases of noODI, ODI_DC, $O D I \_L D C$ and $O D I \_L D C \& D C$ introduced in Section 4.2. Accordingly, Equation (3) is estimated through the Multinomial Logit model, using noODI as a base group (Tables 6a, 6b, 6c).

[Tables 6a, 6b, 6c]

Our most notable finding is that firms exhibiting superior performance tend to choose some ODI involvement rather than none: Sales, Profit, Employees, Value added, Lab prod, TFP, Int assets, Tan assets and Ent value all turn out to be statistically significant with a positive sign, meaning that better enterprises are more likely to experience some outward direct investment. This result is robust to firm, industry and country controls, and it holds irrespective of the specifications, performance measures and ODI class. Put another way, the larger the firm's sales, profit, number of employees, value added, labor and total factor productivity, intangible and tangible assets and enterprise value, the more likely $O D I_{-} D C$ is to prevail over noODI; the same is true for $O D I_{-} L D C$ and ODI_LDC\&DC.

Looking at the magnitude of the performance coefficients, one might push the argument further and infer a performance ranking among ODI types. In particular, in Tables $6 \mathrm{a}, 6 \mathrm{~b}$ and $6 \mathrm{c}$, the performance coefficients for $O D I \_L D C \& D C$ firms tend to be larger than the coefficients for $O D I \_L D C$ firms, which are, in turn, larger than the coefficients for $O D I \_D C$ firms. Consistent with our descriptive statistics reported in Table 3, this evidence suggests that, within the ODI group, the best firms are those having foreign subsidiaries in both developed and developing countries - in other words, the 
most ODI-experienced. Then, firms investing only in LDCs outperform those investing only in DCs on a wide spectrum of performance variables.

These results complement previous evidence on MNEs from advanced economies reported in Damijan et al. (2007), and Aw and Lee (2008). While Slovenian and Taiwanese enterprises investing in DCs tend to outperform those investing in LDCs, the opposite holds true for BRIC firms. In our view, the reason for such evidence should be identified from within the internationalization and performance and the emerging countries' ODI frameworks. The latter emphasizes that MNEs from emerging economies tend to engage in asset-seeking ODI in advanced economies. The former predicts that heterogeneous firms map into different internationalization strategies, in keeping with the SS argument articulated by Melitz (2003). By combining these complementary insights, one could argue that the worst multinationals from BRIC countries self-select into DCs to undertake assetseeking ODI, whereas the best MNEs choose LDCs as a destination for asset-exploiting operations. Indeed, in a LDC framework, the best MNEs face less competition and are more likely to become market leaders in certain high-skilled niches.

Lastly, our forth model focuses on ODI by ownership structure of foreign affiliates:

$$
\text { ODI_own } n_{i}=\alpha \text { performance }_{i}+\beta \text { firm controls }_{i}+\gamma \text { industry controls } \text { country }_{i}+\sigma \text { controls }_{i}+\varepsilon_{i}
$$

In Equation (4), the dependent variable ODI_own captures firm $i$ 's involvement in outward direct investment, based on the four mutually exclusive classes - noODI, ODI_WFOE, ODI_JV and ODI_JV\&WFOE - introduced in Section 4.2. In particular, ODI_own equals 0 if the firm has no foreign subsidiaries, 1 if the firm has only the WFOE-type, 2 if the firm has only the JV-type and 3 if the firm has both WFOE- and JV-types of foreign subsidiaries. Our econometric model is the same as in Equation (3), the only difference being our focus on the ownership structure rather than the destination.

Results from our Multinomial Logit estimates of Equation (4) are displayed in Tables 7a, 7b and 7c.

$$
\text { [Tables 7a, 7b, 7c] }
$$

A first look at the data reveals that better performing enterprises are more likely to engage in ODI rather than belonging to the noODI group. Indeed, Sales, Profit, Employees, Value added, Lab prod, TFP, Int assets, Tan assets and Ent value are all statistically significant with a positive sign, meaning that better firms tend to choose some ODI involvement, rather than none. This result is robust to firm, industry and country controls, and it holds irrespective of the specifications, performance measures and ODI class.

A deeper inspection of Tables $7 \mathrm{a}, 7 \mathrm{~b}$ and $7 \mathrm{c}$ further suggests a performance ranking among the mutually exclusive classes of ODI by ownership structure of foreign affiliates. Notably, the 
performance coefficients for $O D I \_J V \& W F O E$ firms tend to be larger than the coefficients for $O D I J J V$ firms which, in turn, are larger than the coefficients for $O D I \_W F O E$ firms. Consistent with our previous findings reported in Table 3, within the ODI group, the best firms are those having both JVs and WFOEs - in other words, the most ODI-experienced. Then, considering the overall set of our performance variables, firms investing only in JVs outperform those investing only in WFOEs. These results complement previous evidence on ODI and the performance of firms from advanced economies. While Raff et al. (2012) report that Japanese firms engaged in WFOE are, on average, more productive than those engaged in $\mathrm{JV}$, we find contrasting evidence concerning BRIC enterprises. To account for such a different result, one should consider the literature regarding internationalization and performance and emerging countries' ODI. The latter emphasizes that MNEs from emerging economies very often manage their ODI engagement in joint ventures with foreign partners. The former explains that heterogeneous performance could be the result of different internationalization strategies, along the lines of the LI argument articulated by Clerides et al. (1998). ${ }^{31}$ Drawing complementary insights from these two strands, one could argue that JVs enhance the performance of BRIC MNEs, which allows for successful learning through interaction with a foreign partner.

To summarize, our main findings, which are delineated in Tables 5-7, support that which we have previously designated Fact 4. Poisson and Multinomial Logit estimates do indeed confirm that, within the group of BRIC investors, those firms having many foreign affiliates, investing in developing countries, or operating in joint ventures outperform those firms that select other ODI strategies.

\section{Conclusions}

In this paper, we investigated the link between ODI and the performance of BRIC enterprises.

Using firm-level data covering the whole population of industrial companies headquartered in Brazil, Russia, India and China in 2013, we unveiled a number of robust regularities. First, BRIC firms engaged in ODI are in the minority. Second, within the group of BRIC investors, those firms having more than five foreign subsidiaries, investing in developing countries, or operating in joint ventures are in the minority. Third, BRIC firms engaged in ODI outperform domestic enterprises. Fourth, within the group of BRIC investors, those firms having more than five foreign subsidiaries, investing in developing countries, or operating in joint ventures outperform those firms that select other ODI strategies.

These results are robust to several econometric models, definitions of ODI, and measures of performance and specifications including firm, industry and country controls.

\footnotetext{
${ }^{31}$ See also Nam (2013) on the technology catch-up effects of ODI through JVs.
} 
In the Introduction, we claimed that our research question rests on two strands of literature dealing with internationalization and performance and emerging countries' ODI. Having commented extensively on our descriptive statistics and estimation results, we can now discuss to what extent our results contribute to these strands.

As for the first strand, our main prior from internationalization and performance studies is that globally engaged enterprises are the "happy few." We consistently found that BRIC firms engaged in ODI are in the minority (Fact 1), but they outperform domestic enterprises (Fact 3). This clearly complements the empirical evidence of a positive correlation between exports and performance in China and India, as reported in Dai and Yu (2013), Du et al. (2012), Kraay (1999), Li and Yin (2010), Lu (2012), Ma et al. (2014), Park et al. (2010), Van Biesebroeck (2014), Wang et al. (2009), Yang (2008), Yang and Mallick (2010), Haidar (2012) and Mallick and Yang (2013). Interestingly, such a correlation emerges also when we identify internationalization with ODI, rather than exports, and we take a cross-country, rather than a single-country, perspective. Fact 2 and Fact 4 further support this evidence; dissecting ODI by number, destination and ownership structure of foreign affiliates, we generate completely original results. First, the "happy few" story survives regardless of the type of ODI. Second, the deeper the ODI involvement, the larger the performance differential compared with the noODI group. Third, firms selecting relatively less preferred ODI strategies are the best performing. Clearly, these issues could not be addressed by previous studies based on a more elementary taxonomy of international activities. This is a novel contribution by the present paper, inspired by complementary studies on emerging countries' $O D I$.

As for the second strand, our main prior from the literature on emerging countries' $O D I$ is that emerging countries' ODI exhibits a number of distinctive features as compared with investments from advanced economies. In particular, during the last decade, MNEs from emerging countries exhibit a clear tendency toward establishing a wide network of joint ventures in advanced economies. Fact 3 consistently categorizes BRIC firms by different classes of ODI, according to the number, destination and ownership structure of foreign affiliates. While the resulting portrait is in line with previous studies by Child and Rodrigues (2005), Schuller and Turner (2005), Liu and Buck (2009), Yiu et al. (2007), Aybar and Ficici (2009), Gubbi et al. (2010), Makino et al. (2002), Sutherland and Ning (2011) and Piscitello et al. (2015), we take an additional step by asking what is beyond such a portrait. Drawing complementary insights from the literature on internationalization and performance, our answer is that heterogeneous firms undertake different types of ODI (Fact 4). This finding is a novel contribution by the present study and establishes a positive correlation between firm-level performance and certain types of ODI. 
To summarize, marrying the internationalization and performance empirical framework with the emerging countries' ODI taxonomy of outward direct investment, we show that the positive correlation between ODI and performance is both a matter of involvement versus non-involvement in ODI and a matter of the type of ODI that a firm undertakes.

While we believe this result is interesting, we are aware of some data limitations that may hinder our analysis and restrict its scope. For instance, there is an issue of representativeness. Although Orbis has a wide coverage, it is not an exhaustive database for all firms in all countries. This is because administrative datasets typically reflect the population of firms that meet the requirements for inclusion. Therefore, we have resisted the temptation to overgeneralize our results and claim instead that they hold within the sample used for empirical purposes. Another motive of concern involves causality issues. Indeed, the cross-sectional design of our data does not allow for any proper causality analysis. Put another way, while we document a positive and robust correlation between ODI and performance, we cannot discriminate between SS and LI, which is a serious drawback if one plans to derive some policy implications. Lastly, Orbis data allow the development of an unprecedented rich taxonomy of outward direct investment; however, we measure ODI in a rather indirect way, by looking at the host-country isocode. If we were to possess detailed information on either the flows or the stocks of outgoing capital, it would be extremely challenging to check the robustness of our results to a stricter definition of ODI.

These issues all warrant further analysis. 


\section{References}

Alvarez, R. and Lopez, R.A. (2005), 'Exporting and performance: evidence from Chilean plants', Canadian Journal of Economics, 38, 1384-1400.

Amighini, A., Cozza, C., Giuliani, E., Rabellotti, R. and Scalera, V.G. (2015), 'Multinational enterprises from emerging economies: What theories suggest, what evidence shows. A literature review', Journal of Industrial and Business Economics, 42, 343-370.

Andreff, W. (2003), 'The newly emerging TNCs from economies in transition: A comparison with Third World outward FDI', Transnational Corporations, 12, 73-118.

Arbix, G. and Caseiro, L. (2011), 'Destination and strategy of Brazilian multinationals', Economics, Management, and Financial Markets, 6, 207-238.

Athreye, S. and Godley, A. (2009), 'Internationalization and technological leapfrogging in the pharmaceutical industry', Industrial and Corporate Change, 18, 295-323.

Athreye, S. and Kapur, S. (2009), 'Introduction: The internationalization of Chinese and Indian firms - Trends, motivations and strategy', Industrial and Corporate Change, 18, 209-221.

Aw, B.J. and Lee, Y. (2008), 'Firm heterogeneity and location choice for Taiwanese multinationals', Journal of International Economics, 75, 67-179.

Aybar, B. and Ficici, A. (2009), 'Cross-border acquisitions and firm value: An analysis of emergingmarket multinationals', Journal of International Business Studies, 40, 1317-1338.

Barba Navaretti, G. and Castellani, D. (2008), 'Do Italian firms improve their performance at home by investing abroad?', in S. Brakman and H. Garretsen (eds.) Foreign Direct Investment and the Multinational Enterprise. Cambridge MA: MIT Press.

Barba Navaretti, G., Castellani, D. and Disdier A.C. (2010), 'How does investing in cheap labour countries affect performance at home? Firm-level evidence from France and Italy', Oxford Economic Papers, 62, 234-260.

Bernard, A.B. and Jensen, J.B. (1995), 'Exporters, jobs and wages in US manufacturing: 1976-1987', Brookings Papers on Economic Activity, Microeconomics, 67-119.

Blalock G. and Gertler, P.J. (2004), 'Learning from exporting revisited in a less developed setting', Journal of Development Economics, 75, 397-416.

Buckley, P.J., Clegg, J., Cross, A.R., Liu, X., Voss, H. and Zheng, P. (2007), 'The determinants of Chinese outward foreign direct investment', Journal of International Business Studies, 38, 499- 518.

Castellani, D. (2002), 'Firms' technological trajectories and the creation of foreign subsidiaries', International Review of Applied Economics, 16, 359-371.

Castellani, D. Mariotti, I. and Piscitello, L. (2008), 'The impact of outward investments on parent company's employment and skill composition. Evidence from the Italian case', Structural Change and Economic Dynamics, 19, 81-94. 
Chen, W., and Tang, H. (2014), 'The dragon is flying west: Micro-level evidence of Chinese outward direct investment', Asian Development Review, 31, 109-140.

Child, J. and Rodrigues, B. (2005), 'The internationalization of Chinese firms: A case for theoretical extension?', Management and Organization Review, 1, 381-410.

Clerides, S.K., Lach, S. and Tybout, J.R. (1998), 'Is learning by exporting important? Micro-dynamic evidence from Colombia, Mexico and Morocco', Quarterly Journal of Economics, 113, 903-947.

Cozza, C., Rabellotti, R. and Sanfilippo, M. (2015), 'The impact of outward FDI on the performance of Chinese multinationals', China Economic Review, 36, $42-57$.

Cuervo-Cazurra, A. (2007), 'Sequence of value-added activities in the internationalization of developing country MNEs',. Journal of International Management, 13, 258-277.

Cui, L. and Jiang, F. (2012), 'State ownership effect on firms' FDI ownership decisions under institutional pressure: a study of Chinese outward-investing firms', . Journal of International Business Studies, 43, 264-284.

Cui, L., Meyer, K.E. and Hu, H.W. (2014), 'What drives firms' intent to seek strategic assets by foreign direct investment? A study of emerging economy firms', Journal of World Business, 49, 488501.

Dai, M. and Yu, M. (2013), 'Firm R\&D, absorptive capacity and learning by exporting: Firm-level evidence from China', World Economy, 36, 1131-1145.

Damijan, J.P., Polanec, S. and Prasnikar, J. (2007), 'Outward FDI and productivity: Micro-evidence from Slovenia', World Economy, 30, 135-155.

De Abreu Campanario, M., Stal, E. and Muniz da Silva, M. (2013), 'Brazil: Outward FDI and its policy context, 2012',. Iin K.P. Sauvant,. P. Mallampally and G. McAllister (eds.) Inward and Outward FDI Country Profiles, Second Edition 2013. New York: Vale Columbia Center on Sustainable International Investment.

De Beule, F., Elia, S. and Piscitello, L. (2014), 'Entry and access to competencies abroad: emerging market firms versus advanced market firms', Journal of International Management, 20, 137-152.

Demirbas, D., Patnaik, I. and Shah, A. (2013), 'Graduating to globalisation: A study of southern multinationals', Indian Growth and Development Review, 6, 242-259.

Deng, P. (2004), 'Outward investment by Chinese MNCs: Motivations and implications', Business Horizons, 47, 8-16.

Deng, P. (2007), 'Investing for strategic resources and its rationale: The case of outward FDI from Chinese companies', Business Horizons, 50, 71-81.

Deng, P. (2012), 'The internationalization of Chinese firms: A critical review and future research', International Journal of Management Reviews, 14, 408-427. 
Deng, P. (2013), 'Chinese outward direct investment research: Theoretical integration and recommendations', Management and Organization Review, 9, 513-539.

Djankov, S. and Hoekman, B.M. (2000), 'Foreign investment and productivity growth in Czech enterprises', World Bank Economic Review, 14, 49-64.

Du J., Lu, Y., Tao, Z. and Yu, L. (2012), 'Do domestic and foreign exporters differ in learning by exporting? Evidence from China', China Economic Review, 23,: 296-315.

Dunning, J.H. (1993), Multinational Enterprises and the Global Economy. Mass: Addison Wesley.

Duysters, G., Jacob, J., Lemmens, C. and Yu, J. (2009), 'Internationalization and technological catching up of emerging multinationals: A comparative case study of China's Haier group', Industrial and Corporate Change, 18, 325-349.

Edamura, K., Haneda, S., Inui, T., Tan, X. and Todo, Y. (2014), 'Impact of Chinese cross-border outbound M\&As on firm performance: Econometric analysis using firm-level data', China Economic Review, 30, 169-179.

Export-Import Bank of India (2014), 'Outward direct investment from India: Trends, objectives and policy perspectives', Occasional Paper n.165, May.

Fafchamps M., Hamine S.E and Zeufack, A. (2008), 'Learning to export: evidence from Moroccan manufacturing', Journal of African Economics, 17, 305-335.

Fernandes, A.M. (2007), 'Trade policy, trade volumes and plant-level productivity in Colombian manufacturing industries', Journal of International Economics, 71, 52-71.

Fortanier, F., and van Tulder, R. (2009), 'Internationalization trajectories-A cross-country comparison: Are large Chinese and Indian companies different?', Industrial and Corporate Change, 18, 223-247.

Garcia-Herrero, A., and Deorukhakar, S. (2014), 'What explains India's surge in outward direct investment?', Hong Kong: BBVA WP 14/16, June.

Greenaway, D. and Kneller, R. (2007), 'Firm heterogeneity, exporting and foreign direct investment: a Survey', The Economic Journal, 117, F134-F161.

Gubbi, S.R., Aulakh, P., Ray, S., Sarkar, M.B. and Chittoor, R. (2010), 'Do international acquisitions by emerging-economy firms create shareholder value? The case of Indian firms', Journal of International Business Studies, 41, 397-418.

Haidar, J. (2012), 'Trade and productivity: Self-selection or learning-by-exporting in India', Economic Modelling, 29, 1766-1773.

Hayakawa, K., Kimura, F. and Machikita, T. (2012), 'Globalization and productivity: a survey of firm-level analysis', Journal of Economic Surveys, 26, 332-350.

Hijzen, A., Inui, T. and Todo, Y. (2010) Does Offshoring Pay? Firm-Level Evidence From Japan`, Economic Inquiry, 48, 880-895. 
Hijzen, A., Jean, S. and Mayer, T. (2011) The effects at home of initiating production abroad: evidence from matched French firms', Review of World Economics, 147, 457-483.

IMF (1993), Balance of Payments Manual, Fifth Edition. Washington, DC: IMF.

IMF (2014), World Economic Outlook. Legacies, Clouds, Uncertainties. Washington, DC: IMF.

Kalemli-Ozcan, S., Sorensen, B.E., Villegas-Sanchez, C., Volosovych, V. and Yesiltas, S. (2015), 'How to construct nationally representative firm level data from the ORBIS global database.', C.E.P.R. Discussion Papers, CEPR Discussion Papers: 10829.

Kimura, F. and Kiyota, K. (2006), 'Exports, FDI, and productivity: dynamic evidence from Japanese firms', Review of World Economics, 142, 695-719.

Kraay, A. (1999), 'Exports and economic performance: Evidence from a panel of Chinese enterprises', Revue d'Economie du Development, 1, 183-207.

Kumar, N., and Chadha, A. (2009), 'India's outward foreign direct investments in steel industry in a Chinese comparative perspective', Industrial and Corporate Change, 18, 249-267.

Levinsohn, J. and Petrin, A. (2003), 'Estimating Production Functions Using Inputs to Control for Unobservables', Review of Economic Studies, 70, : 317-342.

Li C. and Yin, X. (2010), "The "productivity paradox" of Chinese export firms: review and assessment', China Economist, 25, 74-82

Li, L. (2007), 'Multinationality and performance: A synthetic review and research agenda', International Journal of Management Review, 9, 117-139.

Liu, X. and Buck, T. (2009), 'The Internationalisation strategies of Chinese firms: Lenovo and BOE', Journal of Chinese Economic and Business Studies, 7, 167-181.

Liuhto, K. T. and Majuri, S.S. (2014), 'Outward foreign direct investment from Russia: A literature review', Journal of East-West Business, 20, 198-224.

Lopez, R.A. (2005), 'Trade and growth: Reconciling the macroeconomic and microeconomic evidence', Journal of Economic Surveys, 19, 623-648.

Lu, D. (2012), 'Exceptional exporter performance? Evidence from Chinese manufacturing firms', Working Paper, University of Rochester.

Luo, Y. and Tung, R. L. (2007), 'International expansion of emerging market enterprises: A springboard perspective: Introduction', Journal of International Business Studies, 38, 481-498.

Ma, Y., Tang, H. and Zhang, Y. (2014), 'Factor Intensity, product switching, and productivity: Evidence from Chinese exporters', Journal of International Economics, 92, 349-362.

Makino, S., Lau, C.M. and Yeh, R.S. (2002), 'Asset-exploitation versus asset seeking: Implication for location choice of foreign direct investment from newly industrialized economies', Journal of International Business Studies, 33, 403-421. 
Mallick, S. and Yang, Y. (2013), 'Productivity performance of export market entry and exit: Evidence from Indian firms', Review of International Economics, 21, 809-824.

Mathews, J.A. (2006), 'Catch-up strategies and the latecomer effect in industrial development', New Political Economy, 11, 313-335.

Mayer T. and Ottaviano, G.I.P. (2007) 'The happy few: The internationalisation of European firms', Bruegel Blueprint Series 3. Brussels: Bruegel.

Melitz, M. J. (2003), 'The impact of trade on intra-industry reallocations and aggregate industry productivity', Econometrica, 71, 1695-1725.

Murakami, Y. (2005) Are multinational enterprises more productive? A test of the selection hypothesis', Journal of Asian Economics, 16, 327-339.

Nam, K., \& Li, X. (2013), 'Out of passivity: Potential role of OFDI in IFDI-based learning trajectory', Industrial and Corporate Change, 22, 711-743.

Narula, R. (2006), 'Globalization, new ecologies, new zoologies, and the purported death of the eclectic paradigm', Asia Pacific Journal of Management, 23, 143-151.

Niosi, J. and Tschang, F.T. (2009), 'The strategies of Chinese and Indian software multinationals: Implications for internationalization theory', Industrial and Corporate Change, 18, 269-294.

OECD (1996), OECD Benchmark Definition of Foreign Direct Investment, Third Edition, Paris, OECD.

Park A., Yang D., Shi X. and Jiang, Y. (2010), 'Exporting and firm performance: Chinese exporters and the Asian financial crisis', Review of Economics and Statistics, 92, 822-842.

Piscitello, L., Rabellotti, R. and Scalera V.G. (2015), 'Chinese and Indian acquisitions in Europe: The relationship between motivation and entry mode choice', in A. Risberg, D. King, and O. Meglio (eds.) The Routledge Companion to merger and acquisition. London: Routledge.

Raff, H., Ryan, M. and Stähler, F. (2012), 'Firm Productivity and the Foreign-Market Entry Decision', Journal of Economics \& Management Strategy, 21, 849-871.

Ramamurti, R. (2008), What have we learned about emerging market MNEs? Cambridge, U.K: Cambridge University Press.

Ramamurti, R. (2012), 'What is really different about emerging market multinationals?', Global Strategy Journal, 2, 41-47.

Ramamurti, R. and Singh, J. (2008), 'Emerging multinationals from emerging markets. Cambridge, U.K: Cambridge University Press.

Ramsey, J.R., Bakarat, L.L. and Cretoiu, S.L. (2012), 'Internationalization and its possible impact on subjective and objective performance: Evidence from Brazilian TNCs', Transanational Corporations, 21, 21-46. 
Redding, S. J. (2011), 'Theories of heterogeneous firms and trade', Annual Review of Economics, 3, 77-105.

Sauvant, K.P. (ed.) (2008), The rise of transnational corporations from emerging markets - Threats or opportunity?. Cheltenham: Edward Elgar.

Sauvant, K.P., Economou, P., Gal, K., Lim, S. and Wilinski, W.P. (2014), 'Trends in FDI, home country measures and competitive neutrality', in A.K. Bjorklund (ed) Yearbook on International Investment Law and Policy 2012-2013. New York: Oxford University Press.

Schuller, M. and Turner, A. (2005), 'Global ambitions: Chinese companies spread their wings', China Aktuell-Journal of Current Chinese Affairs, 34, 3-14.

Singh, T. (2010), 'Does international trade cause economic growth? A Survey', The World Economy, 33, 1517-1564

Sutherland, D., and Ning, L. (2011), 'Exploring 'onward-journey' ODI strategies in China's private sector businesses', Journal of Chinese Economic and Business Studies, 9, 43-65.

The Economist (2013), 'The second wave', $26^{\text {th }}$ October.

The Economist (2015), 'Gone shopping', $28^{\text {th }}$ March.

UNCTAD (2005), Case study on outward foreign investment by Russian enterprises. http://unctad.org/en/Docs/c3em26d2a4_en.pdf

UNCTAD (2006), World Investment Report. FDI from Developing and Transition Economies: Implications for Development. Geneva: United Nations.

UNCTAD (2015), World Investment Report 2015. Reforming International Investment Governance. Geneva: United Nations.

Van Biesebroeck, J. (2005), 'Exporting raises productivity in sub-Saharan African manufacturing firms', Journal of International Economics, 67, 373-391.

Van Biesebroeck, J. (2014), 'Productivity, exporting and financial constraints of Chinese SMEs', IDB Working Paper n. 506.

Wagner, J. (2007), 'Exports and productivity: A Survey of the evidence from firm-level data', The World Economy, 30, 60-72.

Wagner, J. (2012), 'International trade and firm performance: A Survey of empirical studies since 2006', Review of World Economics, 148, 235-267.

Wang H., Yang, J. and Lai, M. (2009), 'Export behaviour and firm productivity in China', Journal of Chinese Economic and Business Studies, 7, 409-428.

Wang, C., Hing, H., Kafouros, M. and Boateng, A. (2012), 'What drives outward FDI of Chinese firms? Testing the explanatory power of three theoretical frameworks', International Business Review, 21, 425-438. 
Yang, Y. (2008), 'The Impact of exporting on firm performance: Evidence from Chinese firms', Queen Mary, University of London, mimeo.

Yang, Y. and Mallick, S. (2010), 'Export premium, Self-selection and Learning-by-exporting: Evidence from Chinese matched firms', The World Economy, 33, 1218-1240.

Yasar, M. and Rejesus, R.M. (2005), 'Exporting status and firm performance: Evidence from a matched sample', Economics Letters, 88, 397-402.

Yeung, H. W. and Liu, W. (2008), 'Globalizing China: The rise of mainland firms in the global economy’, Eurasian Geography and Economics, 49, 57-86.

Yiu, D.W., Lau, C.M. and Bruton, G.D. (2007), 'International venturing by emerging economy firms: The effects of firm capabilities, home country networks, and corporate entrepreneurship', Journal of International Business Studies, 38, 519- 540.

Zhang, Y. (2005), China Goes Global. London: The Foreign Policy Centre. 


\section{Appendix}

This section provides the description of all the variables (Table A1), the summary statistics (Table A2) and the correlation matrix of performance variables (Table A3).

[Table A1]

[Table A2]

[Table A3] 


\section{Figures and Tables}

Table 1: ODI, by region and economy, selected years, flows and stocks (billion USD).

\begin{tabular}{|c|c|c|c|c|c|c|c|c|c|c|c|c|c|c|c|c|c|c|c|c|c|c|c|c|c|c|c|c|c|c|c|}
\hline \multirow[t]{3}{*}{ Region/economy } & \multicolumn{6}{|c|}{1995} & \multicolumn{6}{|c|}{ AVG 2005-2007 } & \multicolumn{6}{|c|}{2012} & \multicolumn{6}{|c|}{2013} & \multicolumn{7}{|c|}{2014} \\
\hline & \multicolumn{3}{|c|}{ OUTFLOWS } & \multicolumn{3}{|c|}{ OUSTOCKS } & \multicolumn{3}{|c|}{ OUTFLOWS } & \multicolumn{3}{|c|}{ OUTSTOCKS } & \multicolumn{3}{|c|}{ OUTFLOWS } & \multicolumn{3}{|c|}{ OUTSTOCKS } & \multicolumn{3}{|c|}{ OUTFLOWS } & \multicolumn{3}{|c|}{ OUTSTOCKS } & \multicolumn{4}{|c|}{ OUTFLOWS } & \multicolumn{3}{|c|}{ OUTSTOCKS } \\
\hline & $\Xi$ & $\begin{array}{l}3 \\
3 \\
3 \\
0 \\
0 \\
0\end{array}$ & $\begin{array}{l}0 \\
3 \\
8 \\
0 \\
0\end{array}$ & 气 & $\begin{array}{l}3 \\
3 \\
0 \\
0 \\
0\end{array}$ & 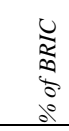 & $\stackrel{\Xi}{\Xi}$ & 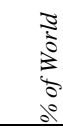 & $\begin{array}{l}0 \\
\frac{8}{80} \\
0 \\
0 \\
0\end{array}$ & ฐ & 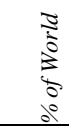 & $\begin{array}{l}0 \\
\frac{2}{20} \\
8 \\
0 \\
0\end{array}$ & $\stackrel{\Xi}{\Xi}$ & $\begin{array}{l}3 \\
0 \\
0 \\
0 \\
0 \\
0\end{array}$ & 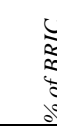 & $\stackrel{\Xi}{\Xi}$ & $\begin{array}{l}3 \\
0 \\
0 \\
0 \\
0 \\
0 \\
0\end{array}$ & 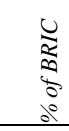 & ฐ & 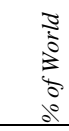 & 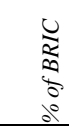 & 气 & $\begin{array}{l}3 \\
3 \\
8 \\
0 \\
0\end{array}$ & 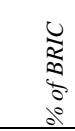 & 气 & 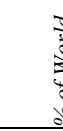 & & 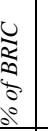 & $\stackrel{\Xi}{\Xi}$ & $\begin{array}{l}3 \\
3 \\
3 \\
0 \\
0 \\
0\end{array}$ & 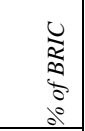 \\
\hline World & 356 & & & 3992 & & & 1423 & & & 14882 & & & 1283 & & & 22527 & & & 1305 & & & 25975 & & & 1354 & & & & 25874 & & \\
\hline Developed economies & 303 & 85.23 & & 3677 & 92.11 & & 1196 & 84.04 & & 12911 & 86.75 & & 872.9 & 68 & & 18105 & 80.37 & & 833.6 & 63.84 & & 21092 & 81.20 & & 822.8 & 60.7 & & & 20554 & 79.44 & \\
\hline Developing economies & 52.1 & 14.60 & & 311.5 & 7.80 & & 193 & 13.63 & & 1720.1 & 11.56 & & 357.2 & 27.83 & & 3965.8 & 17.61 & & 380.8 & 29.16 & & 4354.2 & 16.76 & & 468.1 & 34.5 & & & 4833 & 18.68 & \\
\hline BRIC & 3.82 & 1.07 & & 66.08 & 1.66 & & 74.97 & 5.27 & & 466.45 & 3.13 & & 142.3 & 11.05 & & 1311.1 & 5.82 & & 185.7 & 14.22 & & 1513.7 & 5.83 & & 178.7 & 13.2 & & & 1607.4 & 6.21 & \\
\hline China & 2 & 0.56 & 52.35 & 17.77 & 0.45 & 26.89 & 19.98 & 1.40 & 26.65 & 83.38 & 0.56 & 17.88 & 87.8 & 6.84 & 61.7 & 512.58 & 2.28 & 39.10 & 101 & 7.73 & 54.39 & 613.58 & 2.36 & 40.54 & 116 & 8.57 & 64 & 90 & 729.58 & 2.82 & 45.39 \\
\hline India & 0.12 & 0.03 & 3.11 & 0.50 & 0.01 & 0.75 & 11.5 & 0.81 & 15.34 & 26.95 & 0.18 & 5.78 & 8.85 & 0.66 & 5.96 & 118.07 & 0.52 & 9.01 & 1.68 & 0.13 & 0.90 & 119.84 & 0.46 & 7.92 & 9.85 & 0.73 & 5.5 & & 129.58 & 0.50 & 8.06 \\
\hline Brazil & 1.1 & 0.31 & 28.68 & 44.47 & 1.11 & 67.3 & 12.6 & 0.88 & 16.80 & 111.69 & 0.75 & 23.99 & -2.82 & -0.22 & -1.98 & 270.86 & 1.20 & 20.66 & -3.50 & -0.27 & -1.88 & 300.79 & 1.16 & 19.87 & -3.54 & -0.2 & -1. & & 316.34 & 1.22 & 19.68 \\
\hline Russia & 0.61 & 0.17 & 15.86 & 3.35 & 0.08 & 5.06 & 30.89 & 2.17 & 41.21 & 244.43 & 1.64 & 52.40 & 48.82 & 3.80 & 34.3 & 409.57 & 1.82 & 31.24 & 86.51 & 6.62 & 46.59 & 479.5 & 1.85 & 31.68 & 56.44 & 4.17 & 31. & 57 & 431.87 & 1.67 & 26.87 \\
\hline
\end{tabular}

Source: Authors' elaborations from UNCTAD (2015). 
Table 2: ODI involvement of BRIC firms.

\begin{tabular}{|c|c|c|c|c|c|}
\hline number ( $\%$ total) $[\%$ ODI] & B & $\mathbf{R}$ & $\mathbf{I}$ & $\mathbf{C}$ & total \\
\hline Total & 533 & 1127 & 4300 & 3567 & 9527 \\
\hline noODI & $436(82 \%)$ & $1002(89 \%)$ & $3737(87 \%)$ & $3088(87 \%)$ & $8263(87 \%)$ \\
\hline ODI & $97(18 \%)$ & $125(11 \%)$ & $563(13 \%)$ & $479(13 \%)$ & $1264(13 \%)$ \\
\hline \multicolumn{6}{|l|}{ ODI by number } \\
\hline ODI_1 & $38[39 \%]$ & $59[47 \%]$ & $245[44 \%]$ & $278[58 \%]$ & 620 [49\%] \\
\hline ODI_2-5 & $37[38 \%]$ & $42[34 \%]$ & $211[37 \%]$ & $171[36 \%]$ & $461[36 \%]$ \\
\hline ODI_>5 & $22[23 \%]$ & $24[19 \%]$ & $107[19 \%]$ & $30[6 \%]$ & $183[15 \%]$ \\
\hline \multicolumn{6}{|l|}{ ODI by destination } \\
\hline ODI_LDC & $22[23 \%]$ & $38[30 \%]$ & $86[15 \%]$ & $46[10 \%]$ & $192[15 \%]$ \\
\hline ODI_DC & 30 [31\%] & $39[31 \%]$ & $288[51 \%]$ & $348[72 \%]$ & $705[56 \%]$ \\
\hline ODI_DC\&LDC & $45[46 \%]$ & $48[39 \%]$ & $189[34 \%]$ & $85[18 \%]$ & $367[29 \%]$ \\
\hline \multicolumn{6}{|l|}{ ODI by ownership } \\
\hline ODI_JV & $30[31 \%]$ & $42[33 \%]$ & $130[23 \%]$ & $91[19 \%]$ & $293[23 \%]$ \\
\hline ODI_WFOE & 28 [29\%] & $42[34 \%]$ & $214[38 \%]$ & $277[58 \%]$ & $561[45 \%]$ \\
\hline ODI_JV\&WFOE & $39[40 \%]$ & $41[33 \%]$ & $219[39 \%]$ & $111[23 \%]$ & $410[32 \%]$ \\
\hline
\end{tabular}

Source: Authors' elaborations from Orbis (2014). 
Table 3: Performance differentials of BRIC firms by ODI involvement.

\begin{tabular}{|c|c|c|c|c|c|c|c|c|c|c|c|}
\hline \multirow{3}{*}{\begin{tabular}{|l|} 
\\
Variable \\
\end{tabular}} & \multirow{3}{*}{$\begin{array}{l}\text { noODI } \\
\text { Mean }\end{array}$} & \multirow{3}{*}{$\begin{array}{r}\text { ODI } \\
\text { Mean dif }\end{array}$} & \multicolumn{3}{|c|}{ ODI by number } & \multicolumn{3}{|c|}{ ODI by destination } & \multicolumn{3}{|c|}{ ODI by ownership } \\
\hline & & & \multirow{2}{*}{$\frac{\text { ODI_I }}{\text { Mean dif }}$} & \multicolumn{2}{|c|}{ ODI_2-5 } & \multirow{2}{*}{$\frac{\text { ODI_DC }}{\text { Mean dif }}$} & \multirow{2}{*}{$\frac{\text { ODI_LDC }}{\text { Mean dif }}$} & \multirow{2}{*}{$\begin{array}{l}\text { ODI_LDC_DC } \\
\text { Meandif }\end{array}$} & \multirow{2}{*}{$\begin{array}{l}\text { ODI_WFOE } \\
\text { Mean dif } \\
\end{array}$} & \multirow{2}{*}{ 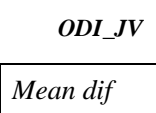 } & \multirow{2}{*}{$\begin{array}{l}\text { ODI_JV_WFOE } \\
\text { Mean dif }\end{array}$} \\
\hline & & & & Mean dif & Mean dif & & & & & & \\
\hline Sales & 295 & $2990^{\mathrm{a}}$ & $1150^{\mathrm{a}}$ & $3109^{a}$ & $8627^{\mathrm{a}}$ & $2023^{\mathrm{a}}$ & $1660^{\mathrm{a}}$ & $5493^{\mathrm{a}}$ & $1174^{\mathrm{a}}$ & $4107^{\mathrm{a}}$ & $4759^{\mathrm{a}}$ \\
\hline Profit & 96 & $1045^{\mathrm{a}}$ & $356^{\mathrm{a}}$ & $681^{\mathrm{a}}$ & $4363^{\mathrm{a}}$ & $476^{\mathrm{a}}$ & $487^{\mathrm{a}}$ & $2428^{\mathrm{a}}$ & $378^{\mathrm{a}}$ & $983^{\mathrm{a}}$ & $2049^{\mathrm{a}}$ \\
\hline Employees & 1573 & $9059^{\mathrm{a}}$ & $4560^{\mathrm{a}}$ & $9200^{\mathrm{a}}$ & $23835^{\mathrm{a}}$ & $6557^{\mathrm{a}}$ & $5529^{\mathrm{a}}$ & $15695^{\mathrm{a}}$ & $5300^{\mathrm{a}}$ & $8850^{\mathrm{a}}$ & $14411^{\mathrm{a}}$ \\
\hline Value added & 37 & $732^{\mathrm{a}}$ & $344^{a}$ & $489^{\mathrm{a}}$ & $2091^{a}$ & $392^{a}$ & $577^{\mathrm{a}}$ & $1333^{\mathrm{a}}$ & $365^{\mathrm{a}}$ & $589^{\mathrm{a}}$ & $1207^{\mathrm{a}}$ \\
\hline Lab prod & 0.3 & $0.1^{\mathrm{b}}$ & $0.10^{\mathrm{a}}$ & $0.12^{\mathrm{b}}$ & $0.14^{\mathrm{b}}$ & $0.003^{\mathrm{a}}$ & $0.01^{\mathrm{a}}$ & $0.19^{\mathrm{a}}$ & 0.02 & 0.03 & $0.15^{\mathrm{a}}$ \\
\hline$T F P$ & 0.6 & $1.8^{\mathrm{a}}$ & $1.21^{\mathrm{a}}$ & $3.36^{\mathrm{a}}$ & $3.39^{\mathrm{a}}$ & 0.17 & 0.35 & $3^{\mathrm{a}}$ & 0.64 & 0.77 & $3^{\mathrm{a}}$ \\
\hline Int assets & 29 & $244^{\mathrm{a}}$ & $109^{\mathrm{a}}$ & $185^{\mathrm{a}}$ & $847^{\mathrm{a}}$ & $121^{\mathrm{a}}$ & $164^{\mathrm{a}}$ & $524^{\mathrm{a}}$ & $110^{\mathrm{a}}$ & $178^{\mathrm{a}}$ & $477^{a}$ \\
\hline Tan assets & 182 & $1929^{\mathrm{a}}$ & $748^{\mathrm{a}}$ & $1494^{\mathrm{a}}$ & $6995^{\mathrm{a}}$ & $1096^{\mathrm{a}}$ & $1109^{\mathrm{a}}$ & $3955^{\mathrm{a}}$ & $704^{a}$ & $2320^{\mathrm{a}}$ & $3344^{\mathrm{a}}$ \\
\hline Ent value & 504 & $2410^{\mathrm{a}}$ & $858^{\mathrm{a}}$ & $1802^{\mathrm{a}}$ & $8407^{\mathrm{a}}$ & $992^{\mathrm{a}}$ & $1972^{\mathrm{a}}$ & $5212^{\mathrm{a}}$ & $1036^{\mathrm{a}}$ & $1959^{\mathrm{a}}$ & $4549^{\mathrm{a}}$ \\
\hline
\end{tabular}

Source: Authors' elaborations from Orbis (2014). 
Table 4: Logit estimates of Equation (1), dependent variable ODI.

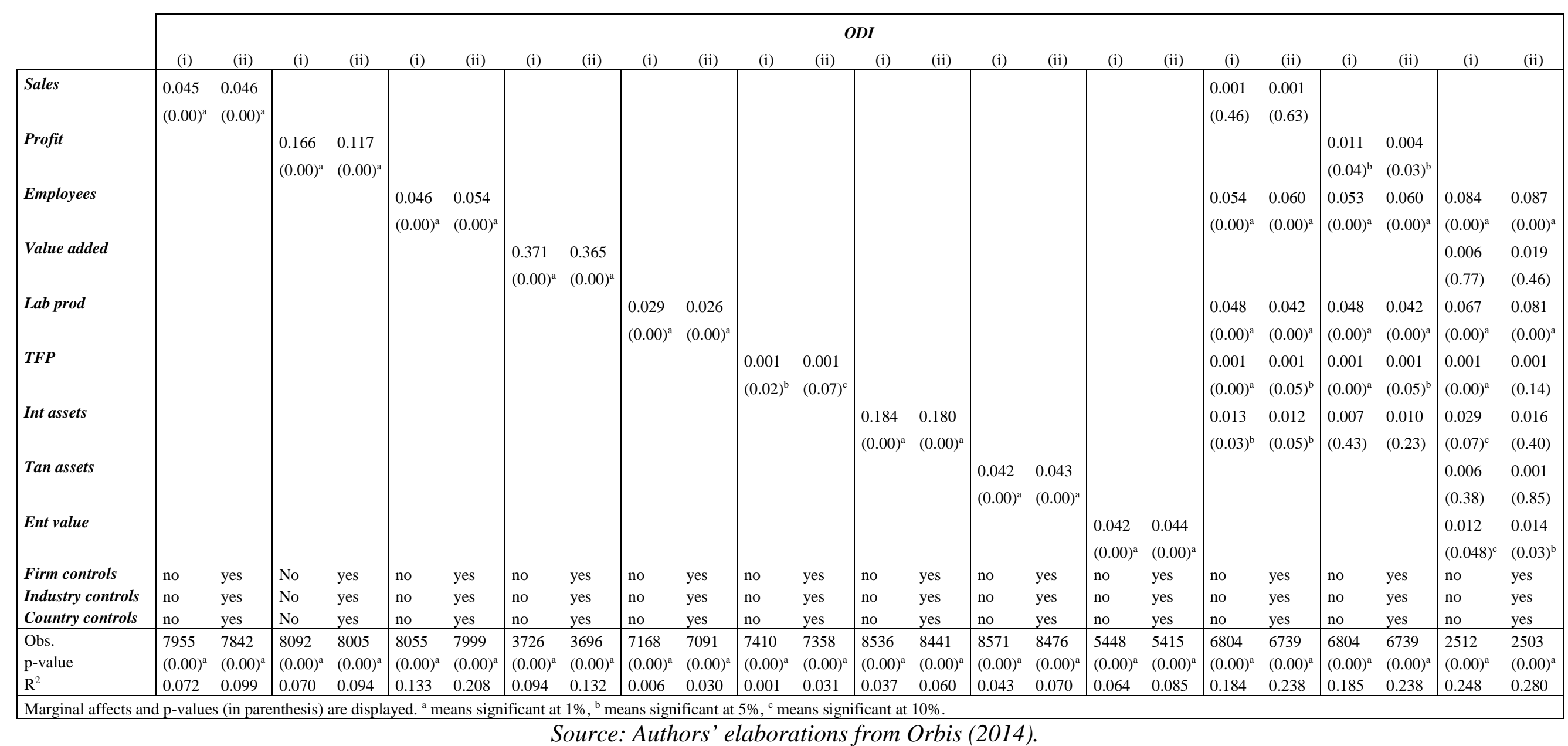


Table 5: Poisson estimates of Equation (2), dependent variable N. subsidiaries.

\begin{tabular}{|c|c|c|c|c|c|c|c|c|c|c|c|c|c|c|c|c|c|c|c|c|c|c|c|c|}
\hline & \multicolumn{24}{|c|}{ N. subsidiaries } \\
\hline & (i) & (ii) & (i) & (ii) & (i) & (ii) & (i) & (ii) & (i) & (ii) & (i) & (ii) & (i) & (ii) & (i) & (ii) & (i) & (ii) & (i) & (ii) & (i) & (ii) & (i) & (ii) \\
\hline Sales & $\begin{array}{l}1.011 \\
(0.00)^{\mathrm{a}}\end{array}$ & $\begin{array}{l}1.138 \\
(0.00)^{\mathrm{a}}\end{array}$ & & & & & & & & & & & & & & & & & $\begin{array}{l}1.001 \\
(0.00)^{\mathrm{a}}\end{array}$ & $\begin{array}{l}1.001 \\
(0.00)^{\mathrm{a}}\end{array}$ & & & & \\
\hline Profit & & & $\begin{array}{l}1.037 \\
(0.00)^{\mathrm{a}}\end{array}$ & $\begin{array}{l}1.053 \\
(0.00)^{\mathrm{a}}\end{array}$ & & & & & & & & & & & & & & & & & $\begin{array}{l}1.002 \\
(0.05)^{\mathrm{c}}\end{array}$ & $\begin{array}{l}1.400 \\
(0.00)^{\mathrm{a}}\end{array}$ & & \\
\hline Employees & & & & & $\begin{array}{l}1.801 \\
(0.00)^{\mathrm{a}}\end{array}$ & $\begin{array}{l}1.902 \\
(0.00)^{\mathrm{a}}\end{array}$ & & & & & & & & & & & & & $\begin{array}{l}1.884 \\
(0.00)^{\mathrm{a}}\end{array}$ & $\begin{array}{l}2.058 \\
(0.00)^{\mathrm{a}}\end{array}$ & $\begin{array}{l}1.810 \\
(0.00)^{\mathrm{a}}\end{array}$ & $\begin{array}{l}1.600 \\
(0.00)^{\mathrm{a}}\end{array}$ & & \\
\hline Value added & & & & & & & $\begin{array}{l}1.065 \\
(0.00)^{\mathrm{a}}\end{array}$ & $\begin{array}{l}1.705 \\
(0.00)^{\mathrm{a}}\end{array}$ & & & & & & & & & & & & & & & & \\
\hline Lab prod & & & & & & & & & $\begin{array}{l}1.457 \\
(0.00)^{\mathrm{a}}\end{array}$ & $\begin{array}{l}1.423 \\
(0.00)^{\mathrm{a}}\end{array}$ & & & & & & & & & $\begin{array}{l}1.808 \\
(0.00)^{\mathrm{a}}\end{array}$ & $\begin{array}{l}1.755 \\
(0.00)^{\mathrm{a}}\end{array}$ & $\begin{array}{l}1.706 \\
(0.00)^{\mathrm{a}}\end{array}$ & $\begin{array}{l}1.383 \\
(0.00)^{\mathrm{a}}\end{array}$ & $\begin{array}{l}1.339 \\
(0.00)^{\mathrm{a}}\end{array}$ & $\begin{array}{l}1.316 \\
(0.00)^{\mathrm{a}}\end{array}$ \\
\hline$T F P$ & & & & & & & & & & & $\begin{array}{l}1.001 \\
(0.01)^{b}\end{array}$ & $\begin{array}{l}1.000 \\
(0.75)\end{array}$ & & & & & & & $\begin{array}{l}1.006 \\
(0.00)^{\mathrm{a}}\end{array}$ & $\begin{array}{l}1.002 \\
(0.02)^{\mathrm{b}}\end{array}$ & $\begin{array}{l}1.005 \\
(0.00)^{\mathrm{a}}\end{array}$ & $\begin{array}{l}1.01 \\
(0.00)^{\mathrm{a}}\end{array}$ & $\begin{array}{l}1.003 \\
(0.01)^{\mathrm{b}}\end{array}$ & $\begin{array}{l}1.991 \\
(0.48)\end{array}$ \\
\hline Int assets & & & & & & & & & & & & & $\begin{array}{l}1.414 \\
(0.00)^{\mathrm{a}}\end{array}$ & $\begin{array}{l}1.367 \\
(0.00)^{\mathrm{a}}\end{array}$ & & & & & $\begin{array}{l}1.022 \\
(0.00)^{\mathrm{a}}\end{array}$ & $\begin{array}{l}0.999 \\
(0.96)\end{array}$ & $\begin{array}{l}0.994 \\
(0.60)\end{array}$ & $\begin{array}{l}0.738 \\
(0.00)^{\mathrm{a}}\end{array}$ & $\begin{array}{l}1.292 \\
(0.00)^{\mathrm{a}}\end{array}$ & $\begin{array}{l}1.179 \\
(0.00)^{\mathrm{a}}\end{array}$ \\
\hline Tan assets & & & & & & & & & & & & & & & $\begin{array}{l}1.018 \\
(0.00)^{\mathrm{a}}\end{array}$ & $\begin{array}{l}1.015 \\
(0.00)^{\mathrm{a}}\end{array}$ & & & & & & & $\begin{array}{l}1.003 \\
(0.00)^{\mathrm{a}}\end{array}$ & $\begin{array}{r}1.006 \\
(0.00)^{\mathrm{a}}\end{array}$ \\
\hline Ent value & & & & & & & & & & & & & & & & & 1.034 & 1.027 & & & & & 1.070 & 1.059 \\
\hline $\begin{array}{l}\text { Firm controls } \\
\text { Industry controls } \\
\text { Country controls }\end{array}$ & $\begin{array}{l}\text { no } \\
\text { no } \\
\text { no }\end{array}$ & $\begin{array}{l}\text { yes } \\
\text { yes } \\
\text { yes }\end{array}$ & $\begin{array}{l}\text { No } \\
\text { No } \\
\text { No }\end{array}$ & $\begin{array}{l}\text { yes } \\
\text { yes } \\
\text { yes }\end{array}$ & $\begin{array}{l}\text { no } \\
\text { no } \\
\text { no }\end{array}$ & $\begin{array}{l}\text { yes } \\
\text { yes } \\
\text { yes }\end{array}$ & $\begin{array}{l}\text { no } \\
\text { no } \\
\text { no }\end{array}$ & $\begin{array}{l}\text { yes } \\
\text { yes } \\
\text { yes }\end{array}$ & $\begin{array}{l}\text { no } \\
\text { no } \\
\text { no }\end{array}$ & $\begin{array}{l}\text { yes } \\
\text { yes } \\
\text { yes }\end{array}$ & $\begin{array}{l}\text { no } \\
\text { no } \\
\text { no }\end{array}$ & $\begin{array}{l}\text { yes } \\
\text { yes } \\
\text { yes }\end{array}$ & $\begin{array}{l}\text { no } \\
\text { no } \\
\text { no }\end{array}$ & $\begin{array}{l}\text { yes } \\
\text { yes } \\
\text { yes }\end{array}$ & $\begin{array}{l}\text { no } \\
\text { no } \\
\text { no }\end{array}$ & $\begin{array}{l}\text { yes } \\
\text { yes } \\
\text { yes }\end{array}$ & $\begin{array}{l}(0.00)^{\mathrm{a}} \\
\text { no } \\
\text { no } \\
\text { no }\end{array}$ & $\begin{array}{l}(0.00)^{\mathrm{a}} \\
\text { yes } \\
\text { yes } \\
\text { yes }\end{array}$ & $\begin{array}{l}\text { no } \\
\text { no } \\
\text { no }\end{array}$ & $\begin{array}{l}\text { yes } \\
\text { yes } \\
\text { yes }\end{array}$ & $\begin{array}{l}\text { no } \\
\text { no } \\
\text { no }\end{array}$ & $\begin{array}{l}\text { yes } \\
\text { yes } \\
\text { yes }\end{array}$ & $\begin{array}{l}(0.00)^{\mathrm{a}} \\
\text { no } \\
\text { no } \\
\text { no }\end{array}$ & $\begin{array}{l}(0.00)^{\mathrm{a}} \\
\text { yes } \\
\text { yes } \\
\text { yes }\end{array}$ \\
\hline $\begin{array}{l}\text { Obs. } \\
\text { p-value } \\
\mathrm{R}^{2}\end{array}$ & $\begin{array}{l}7955 \\
(0.00)^{\mathrm{a}} \\
0.024\end{array}$ & $\begin{array}{l}7855 \\
(0.00)^{\mathrm{a}} \\
0.067\end{array}$ & $\begin{array}{l}8092 \\
(0.00)^{\mathrm{a}} \\
0.041\end{array}$ & $\begin{array}{l}8005 \\
(0.00)^{\mathrm{a}} \\
0.080\end{array}$ & $\begin{array}{l}8055 \\
(0.00)^{\mathrm{a}} \\
0.241\end{array}$ & $\begin{array}{l}7999 \\
(0.00)^{\mathrm{a}} \\
0.365\end{array}$ & $\begin{array}{l}3726 \\
(0.00)^{\mathrm{a}} \\
0.042\end{array}$ & $\begin{array}{l}3701 \\
(0.00)^{\mathrm{a}} \\
0.102\end{array}$ & $\begin{array}{l}7168 \\
(0.00)^{\mathrm{a}} \\
0.023\end{array}$ & $\begin{array}{l}7155 \\
(0.00)^{\mathrm{a}} \\
0.098\end{array}$ & $\begin{array}{l}7410 \\
0.04^{b} \\
0.020\end{array}$ & $\begin{array}{l}7361 \\
(0.00)^{\mathrm{a}} \\
0.075\end{array}$ & $\begin{array}{l}8536 \\
(0.00)^{\mathrm{a}} \\
0.069\end{array}$ & $\begin{array}{l}8441 \\
(0.00)^{\mathrm{a}} \\
0.122\end{array}$ & $\begin{array}{l}8571 \\
(0.00)^{\mathrm{a}} \\
0.032\end{array}$ & $\begin{array}{l}8476 \\
(0.00)^{\mathrm{a}} \\
0.092\end{array}$ & $\begin{array}{l}5448 \\
(0.00)^{\mathrm{a}} \\
0.071\end{array}$ & $\begin{array}{l}5417 \\
(0.00)^{\mathrm{a}} \\
0.131\end{array}$ & $\begin{array}{l}6804 \\
(0.00)^{\mathrm{a}} \\
0.308\end{array}$ & $\begin{array}{l}6755 \\
(0.00)^{\mathrm{a}} \\
0.409\end{array}$ & $\begin{array}{l}6804 \\
(0.00)^{\mathrm{a}} \\
0.305\end{array}$ & $\begin{array}{l}6755 \\
(0.00)^{\mathrm{a}} \\
0.438\end{array}$ & $\begin{array}{l}4879 \\
(0.00)^{\mathrm{a}} \\
0.114\end{array}$ & $\begin{array}{l}4857 \\
(0.00)^{\mathrm{a}} \\
0.166\end{array}$ \\
\hline
\end{tabular}

Source: Authors' elaborations from Orbis (2014). 
Table 6a: Multinomial logit estimates of Equation (3), dependent variable ODI_dest, pure specifications without firm, industry and country controls.

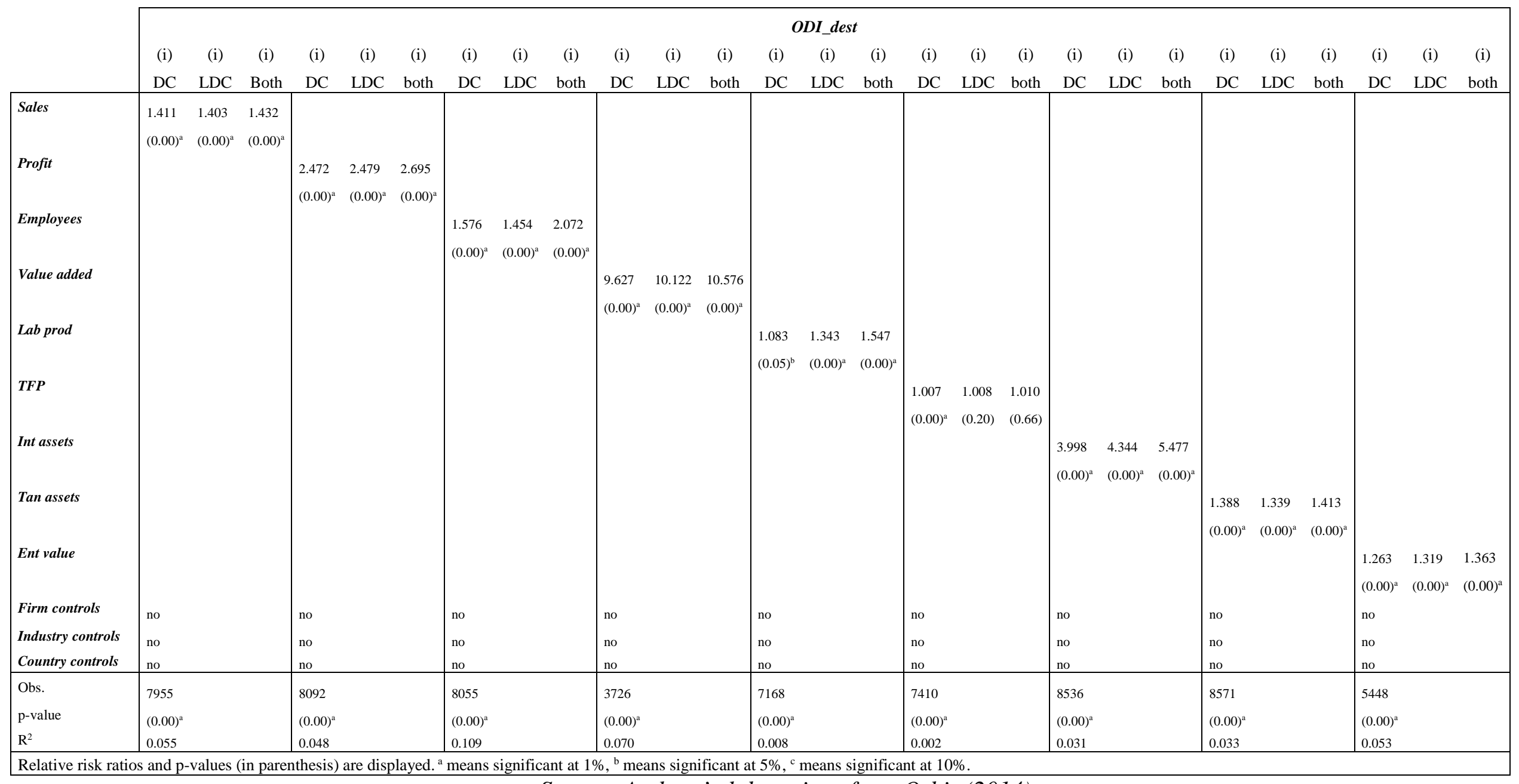

Source: Authors' elaborations from Orbis (2014). 
Table 6b: Multinomial logit estimates of Equation (3), dependent variable ODI_dest, pure specifications, firm, industry and country controls included.

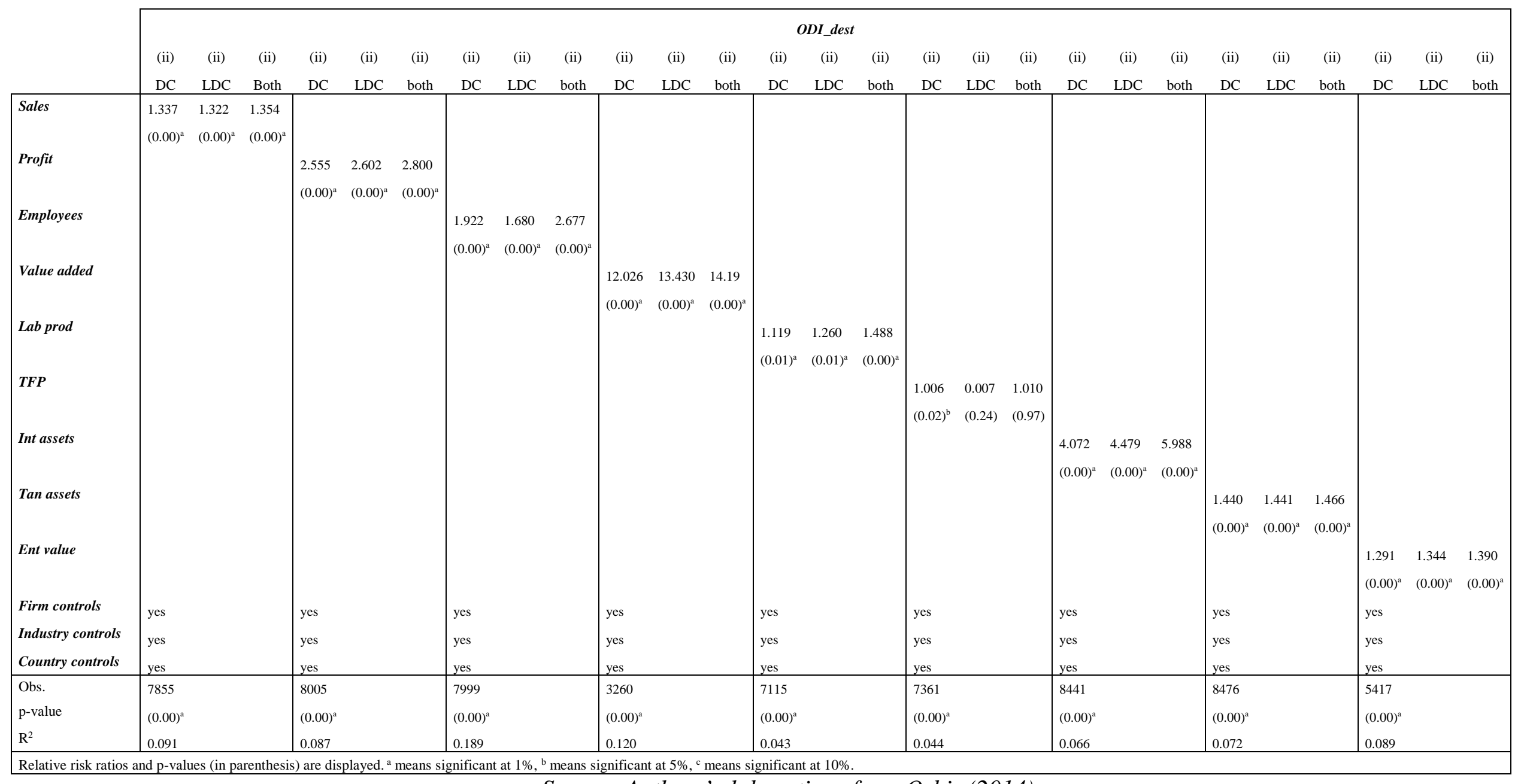

Source: Authors' elaborations from Orbis (2014). 
Table 6c: Multinomial logit estimates of Equation (3), dependent variable ODI_dest, mixed specifications.

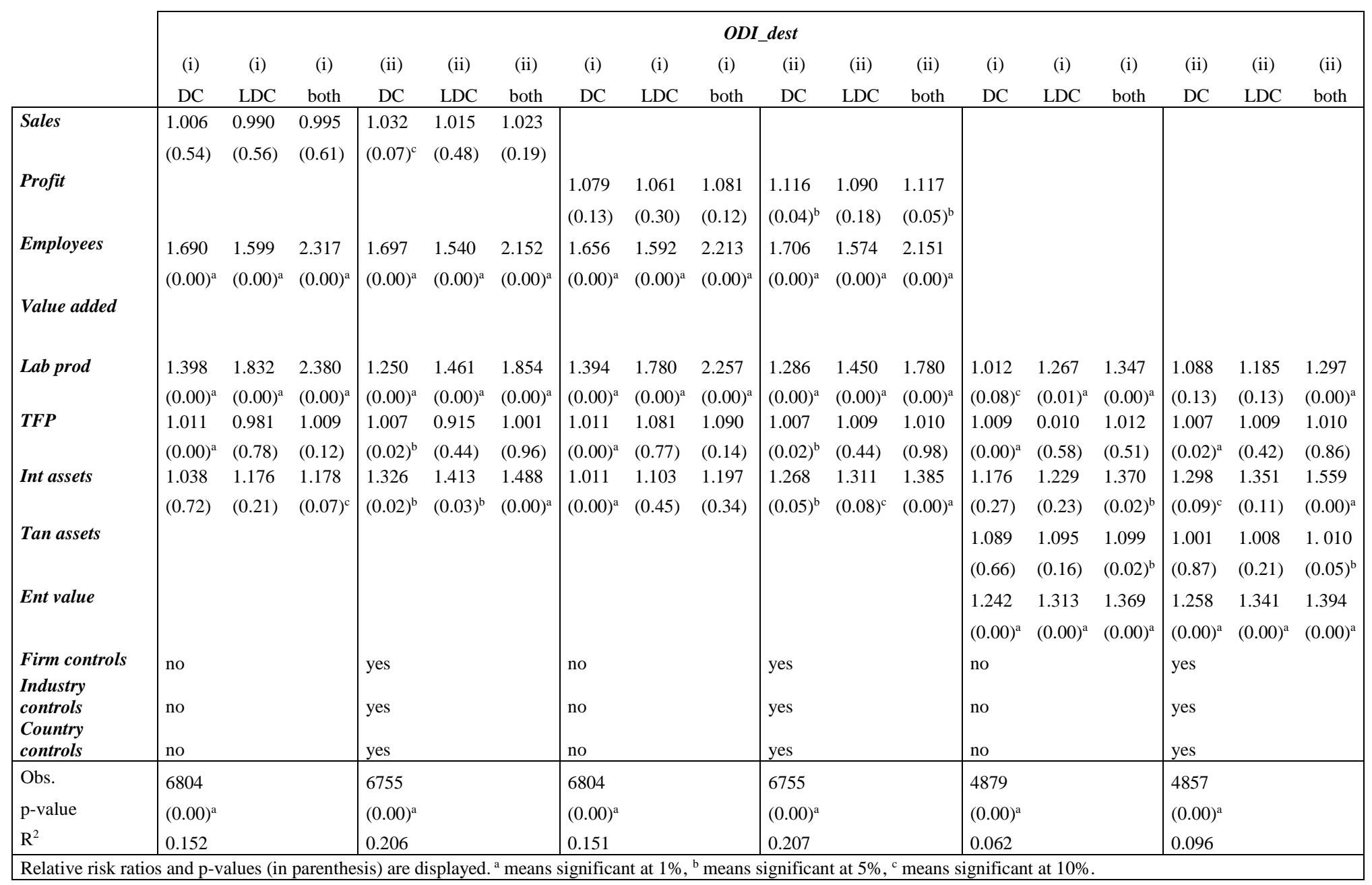

Source: Authors' elaborations from Orbis (2014). 
Table 7a: Multinomial logit estimates of Equation (4), dependent variable ODI_own, pure specifications without firm, industry and country controls.

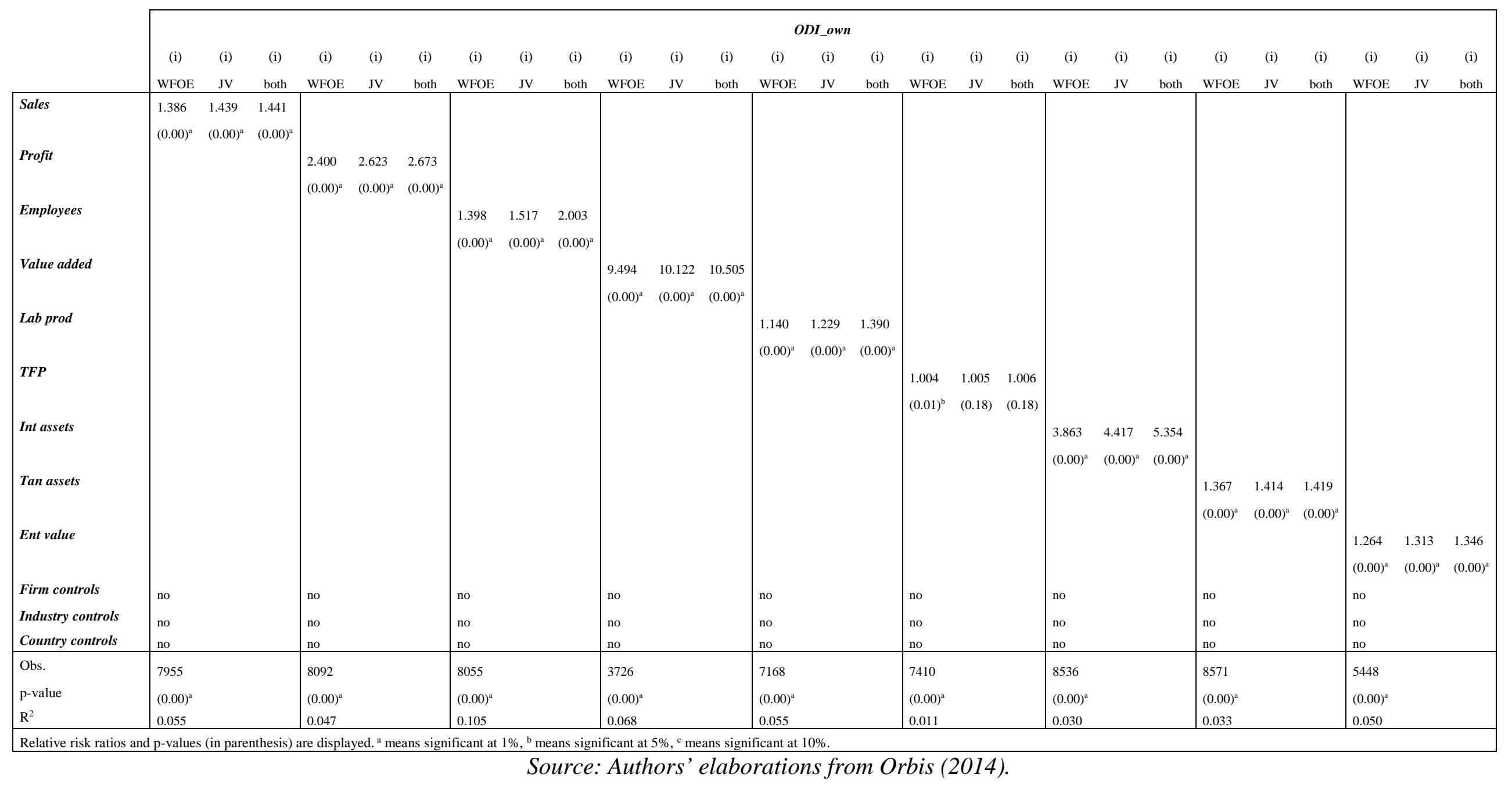


Table 7b: Multinomial logit estimates of Equation (4), dependent variable ODI_own, pure specifications, firm, industry and country controls included.

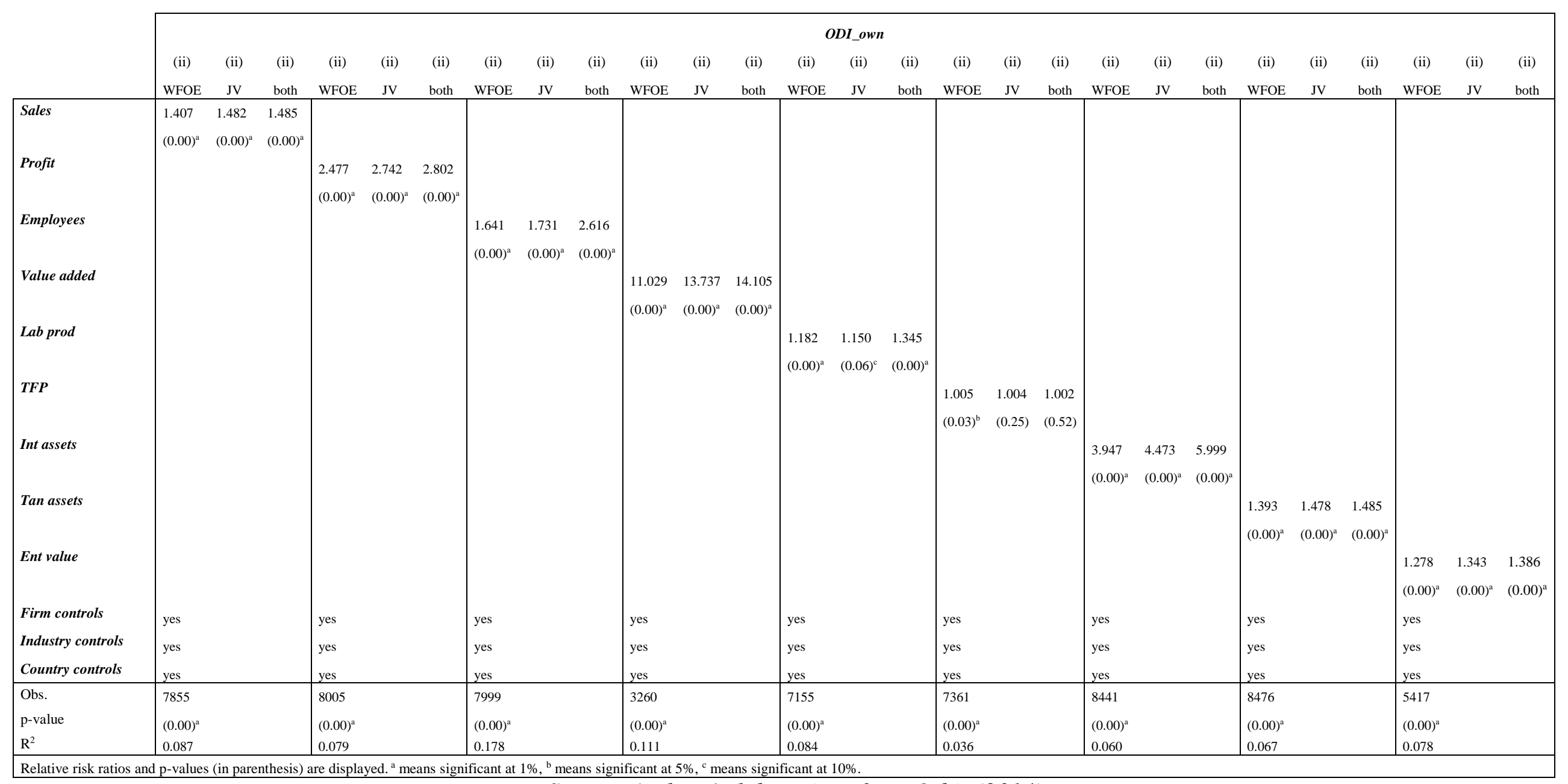

Source: Authors' elaborations from Orbis (2014). 
Table 7c: Multinomial logit estimates of Equation (4), dependent variable ODI_own, mixed specifications.

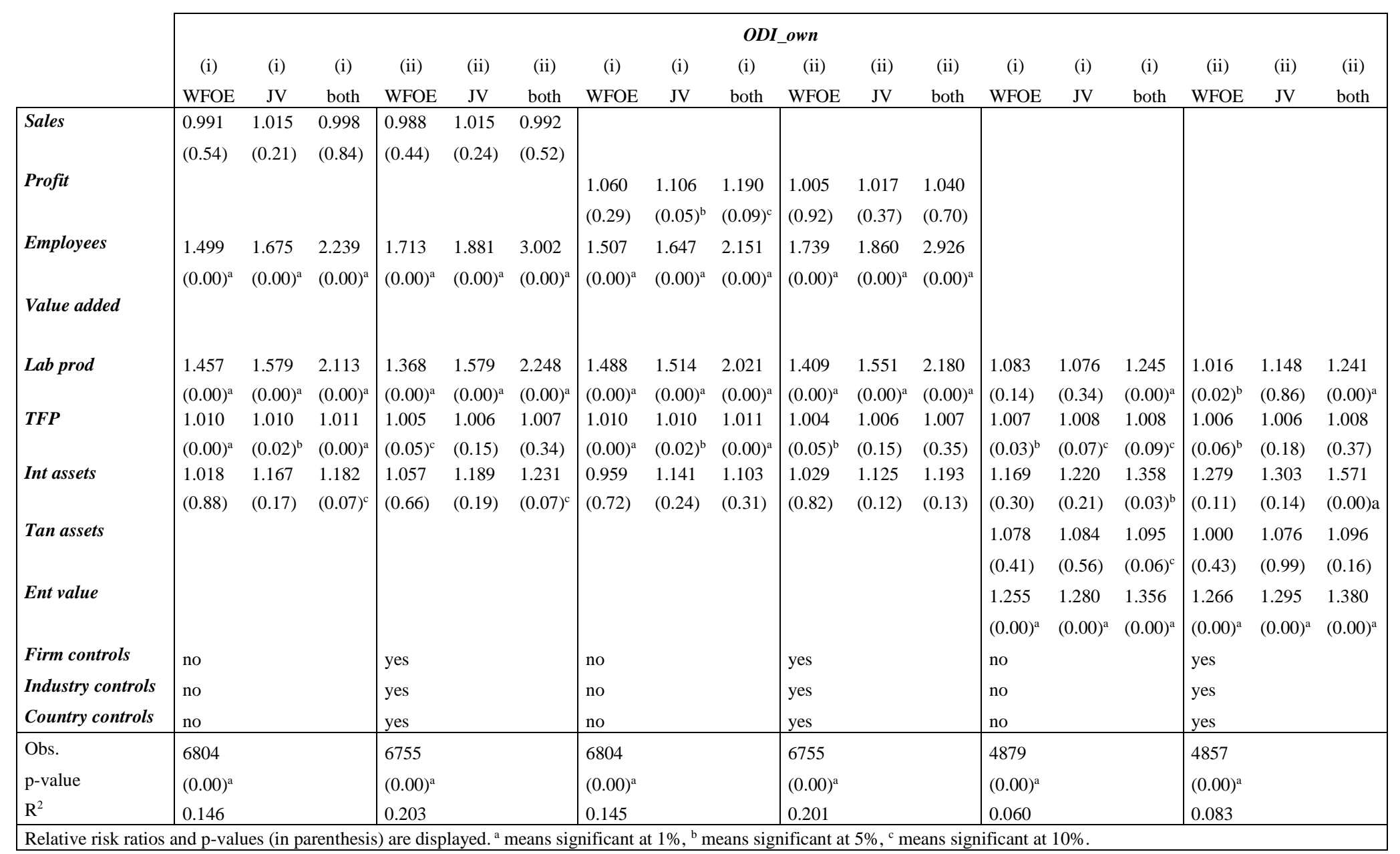

Source: Authors' elaborations from Orbis (2014). 


\section{Table A1: Variables description.}

\begin{tabular}{|c|c|}
\hline Variable & Description \\
\hline ODI & Dummy variable; 1 if the firm has at least one foreign subsidiary, 0 otherwise. \\
\hline noODI & Dummy variable; 1 if the firm has no foreign subsidiary, 0 otherwise. \\
\hline N_subs & Number of foreign subsidiaries. \\
\hline ODI_1 & Dummy variable; 1 if the firm has only one foreign subsidiary, 0 otherwise. \\
\hline ODI_2-5 & Dummy variable; 1 if the firm has from two to five foreign subsidiaries, 0 otherwise. \\
\hline ODI_>5 & Dummy variable; 1 if the firm has more than five foreign subsidiaries, 0 otherwise. \\
\hline ODI_LDC & Dummy variable; 1 if the firm has foreign subsidiaries only in LDCs, 0 otherwise. \\
\hline$O D I \_D C$ & Dummy variable; 1 if the firm has foreign subsidiaries only in DCs, 0 otherwise. \\
\hline ODI_LDC\&DC & Dummy variable; 1 if the firm has foreign subsidiaries in both LDCs and DCs, 0 otherwise. \\
\hline ODI_JV & Dummy variable; 1 if the firm has only JV-type of foreign subsidiaries, 0 otherwise. \\
\hline ODI_WFOE & Dummy variable; 1 if the firm has only WFOE-type of foreign subsidiaries, 0 otherwise. \\
\hline ODI_JV\&WFOE & $\begin{array}{l}\text { Dummy variable; } 1 \text { if the firm has both JV- and WFOE-types of foreign subsidiaries, } 0 \\
\text { otherwise. }\end{array}$ \\
\hline ODI_dest & Discrete variable; 0 if $n o O D I, 1$ if $O D I \_D C, 2$ if $O D I \_L D C, 3$ if $O D I \_L D C \& D C$. \\
\hline ODI_own & Discrete variable; 0 if noODI, 1 if $O D I \_W F O E, 2$ if $O D I \_J V, 3$ if $O D I \_J V \& W F O E$. \\
\hline Sales & Firm's sales (million USD). \\
\hline Profit & Firm's profit (million USD). \\
\hline Employees & Firm's number of employees. \\
\hline Value added & Firm's value added (million USD). \\
\hline Lab Prod & Labour productivity, defined as Sales over Employees. \\
\hline TFP & $\begin{array}{l}\text { Natural logarithm of firm's total factor productivity. Total factor productivity is estimated } \\
\text { according to the Levinsohn and Petrin ( } 2003 \text { ) method, to deal with simultaneity and selection } \\
\text { bias. In particular, we assume the production function of firm i, at a given point in time, to be } \\
\text { Cobb-Douglas, and the logarithm of firm's output (measured by operating revenues) to be a } \\
\text { function of the logarithm of the freely variable inputs labour (measured by the number of } \\
\text { employees) and intermediate input (measured by the cost of good sold) and the logarithm of the } \\
\text { state variable capital (measured by tangible fixed assets). }\end{array}$ \\
\hline Int assets & Firm's intagible assets (million USD). \\
\hline Tan assets & Firm's tangible assets (million USD). \\
\hline Ent value & $\begin{array}{l}\text { Enterprise value, computed as calculated as the market capitalization plus debt, minority interest } \\
\text { and preferred shares, minus total cash and cash equivalents. }\end{array}$ \\
\hline Firm controls & $\begin{array}{l}\text { Firm controls is a matrix containing three firm-level control variables, i.e. firm's age (defined as } \\
2013 \text { - year of foundation), a dummy for large companies and a dummy for listed companies. }\end{array}$ \\
\hline Industry controls & $\begin{array}{l}\text { Industry controls is a matrix containing } 21 \text { industry-level control variables, i.e. NACE 2-digit } \\
\text { industry dummies. }\end{array}$ \\
\hline Country controls & $\begin{array}{l}\text { Country controls is a matrix containing four country -level control variables, i.e. a dummy for } \\
\text { Brazil, a dummy for Russia, a dummy for India and a dummy for China. }\end{array}$ \\
\hline
\end{tabular}


Table A2: Summary statistics of performance variables.

\begin{tabular}{|l|lllll|}
\hline variable & obs & Mean & std.dev. & min & max \\
\hline Sales & 7955 & 0.746 & 6.754 & 0 & 433 \\
Profit & 8092 & 0.250 & 2.617 & -1.970 & 138 \\
Employees & 8055 & 5.760 & 2.417 & 0 & 13.207 \\
Value added & 3726 & 0.169 & 1.727 & -0.419 & 75 \\
Lab prod & 7168 & 5.151 & 0.989 & -3.377 & 11.241 \\
TFP & 7410 & 0.844 & 17.707 & 0.001 & 1222.039 \\
Int assets & 8536 & 0.065 & 0.465 & 0 & 15.3 \\
Tan assets & 8571 & 0.460 & 5.211 & 0 & 273 \\
Ent value & 5448 & 0.983 & 4.633 & -2.560 & 137 \\
\hline
\end{tabular}

Source: Authors' elaborations from Orbis (2014).

Table A3: Correlation matrix of performance variables.

\begin{tabular}{|c|c|c|c|c|c|c|c|c|c|}
\hline & ֶัँ & $\stackrel{5}{E}$ & & 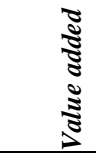 & $\begin{array}{l}3 \\
5 \\
3 \\
3 \\
3\end{array}$ & $\underset{E}{E}$ & $\begin{array}{l}\tilde{\Xi} \\
\tilde{\Xi} \\
\Xi \\
\Xi\end{array}$ & $\begin{array}{l}\tilde{\Xi} \\
\tilde{5} \\
\Xi \\
\Xi\end{array}$ & 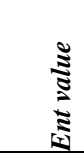 \\
\hline Sales & 1.0000 & & & & & & & & \\
\hline Profit & 0.6357 & 1.0000 & & & & & & & \\
\hline Employees & 0.2203 & 0.2085 & 1.0000 & & & & & & \\
\hline Value added & 0.7579 & 0.9195 & 0.2529 & 1.0000 & & & & & \\
\hline Lab prod & 0.1003 & 0.0794 & 0.1842 & 0.066 & 1.0000 & & & & \\
\hline$T F P$ & 0.0060 & 0.0037 & 0.0002 & 0.0046 & 0.1118 & 1.0000 & & & \\
\hline Int assets & 0.3245 & 0.4397 & 0.2897 & 0.4742 & 0.0631 & 0.0056 & 1.0000 & & \\
\hline Tan assets & 0.7359 & 0.9294 & 0.2049 & 0.9679 & 0.0850 & 0.0061 & 0.3829 & 1.0000 & \\
\hline Ent value & 0.7525 & 0.8731 & 0.3199 & 0.8940 & 0.0961 & 0.0057 & 0.4967 & 0.8716 & 1.0000 \\
\hline
\end{tabular}

Source: Authors' elaborations from Orbis (2014). 